\title{
Characterizing shrimp-farm production intensity in Thailand: beyond technical indices
}

Article

Accepted Version

Creative Commons: Attribution-Noncommercial-No Derivative Works 4.0

Elwin, A., Jintana, V. and Feola, G. (2020) Characterizing shrimp-farm production intensity in Thailand: beyond technical indices. Ocean \& Coastal Management, 185. 105019. ISSN 0964-5691 doi:

https://doi.org/10.1016/j.ocecoaman.2019.105019 Available at https://centaur.reading.ac.uk/87280/

It is advisable to refer to the publisher's version if you intend to cite from the work. See Guidance on citing.

To link to this article DOI: http://dx.doi.org/10.1016/j.ocecoaman.2019.105019

Publisher: Elsevier

All outputs in CentAUR are protected by Intellectual Property Rights law, including copyright law. Copyright and IPR is retained by the creators or other copyright holders. Terms and conditions for use of this material are defined in the End User Agreement.

www.reading.ac.uk/centaur 
Central Archive at the University of Reading

Reading's research outputs online 
1 Characterizing shrimp-farm production intensity in Thailand: Beyond technical

2 indices.

Angie Elwin ${ }^{a^{*}}$, Vipak Jintana ${ }^{\mathrm{b}}$, Giuseppe Feolac ${ }^{\mathrm{c}}$

${ }^{a}$ Department of Geography and Environmental Science, University of Reading, Whiteknights - PO Box 227, RG66AB, Reading, United Kingdom.

${ }^{b}$ Department of Forest Management, Faculty of Forestry, Kasetsart University, Bangkok 10900, Thailand.fforvij@ku.ac.th.

${ }^{c}$ Copernicus Institute of Sustainable Development, Utrecht University, Section of Environmental Governance, Princetonlaan 8, 3584 CB Utrecht, PO Box 80115, 3508 TC Utrecht, The Netherlands.feola@uu.nl.

*Corresponding author. Department of Geography and Environmental Science, University of Reading, Whiteknights - PO Box 227, RG66AB, Reading, United Kingdom. E-mail address: angie.elwin@reading.ac.uk.

\section{Abstract}

This study examines shrimp farmer behaviour in relation to production intensity along the eastern coast of the Gulf of Thailand, and its embeddedness in the wider socio-economic context of shrimp farming households. The integrative agent-centred (IAC) framework was used as a basis for designing a structured survey to collect semi-quantitative data for a range of explanatory variables that potentially drive shrimp farmer behaviour. The results show that shrimp farming intensity is associated with a combination of technical (e.g. farm area, pond size, stocking density and production), economic (shrimp selling price, production costs and farm revenue), social (e.g. farm operating years, the use of family labour, engagement in shrimp farming and with other shrimp farmers), and ecological factors (e.g. farmer reliance on natural pond productivity, and constraints brought about by environmental change and fluctuations in productive areas). In addition, the results indicate that a number of external and internal socio-economic factors are related to the decision to adopt a certain level of production intensity, including training received on farming practices, access to technical equipment, proportion of total income from shrimp farming, season-specific changes in production, risk perception, and subjective culture (social norms and roles). This study therefore illustrates that levels of shrimp farming intensity are in fact an indicator of a diversity of socio-economic conditions and behavioural choices, which need to be targeted by sustainability policies differentially and beyond the technical sphere. In showing this, we 
conclude that national standards aimed at achieving aquaculture sustainability should be designed to reflect the diversity needed to support such a diverse sector, and should be adjustable to better represent different socio-economic contexts.

Keywords: shrimp aquaculture; farming intensity; farmer behaviour; sustainability

\section{Introduction}

\subsection{Shrimp farming sustainability}

With the continued downward trend in the overall state of the world's marine fish stocks (Pauly and Zeller, 2016), the aquaculture sector increasingly plays a major role in meeting the ever-growing human demand for fish and other aquatic products (FAO, 2018; Belton et al., 2014; Hall et al., 2011a). Total worldwide aquaculture production reached about 80 million tonnes in 2016, estimated to be worth USD 232 billion (FAO, 2018). Globally, aquaculture supports livelihoods and contributes to food and economic security by delivering sources of animal protein, nutrients, and income (Belhabib et al., 2015; Smith et al., 2010; Godfray et al., 2010).

However, aquaculture is often associated with environmental sustainability issues. Major environmental issues have been documented since the 1990s. These include widespread destruction and conversion of coastal ecosystems (Alongi, 2002; Richards and Friess, 2016; Valiela et al., 2001), direct loss of fisheries and coastal biodiversity (Naylor et al., 1998, 2000, 2009; Diana, 2009; Polidoro et al., 2010), salinization of groundwater and transformation of agricultural land (Cardoso-Mohedano et al., 2018), high rates of natural resource consumption (Boyd and McNevin, 2015), eutrophication of coastal waters and disease outbreaks (Naylor et al., 1998, 2000; Herbeck et al., 2013), and large fish meal and fish oil requirements which has put direct pressure on wild fish stocks (Tacon and Metian, 2008). Environmental changes have also led to negative consequences for coastal communities, including displacement and loss of local livelihood, increased vulnerability to flooding, and loss of many essential services provided by intact ecosystems (Primavera, 1997, 2006; Neiland et al., 2001; Paul and Vogl, 2011). In response, there have been calls for more sustainable aquaculture production (FAO, 2016a).

Thailand first developed national certification standards for aquaculture production in the late 1990s, and currently, three state-initiated certification standards exist, including the 
100 Good Aquaculture Practice (GAP), Code of Conduct (CoC) and, most recently, the GAP-

1017401 (Samerwong et al., 2018). These standards set requirements for shrimp producers aimed

102 at improving farming practices, environmental integrity and social responsibility, and

103 mitigating problems of disease, which presents a significant risk to producers across farm

104 intensity types, from the small-scale family operations to the highly intensive corporate-run

105 farms (Cock et al., 2015).

106 While Thai state-initiated standards attempt to be inclusive across producers of 107 varying intensity and capability, two crucial issues can be identified as challenges for the 108 promotion of sustainable aquaculture. First, policy-makers have had difficulties in tailoring 109 sustainability policies and strategies to match the diversity of aquaculture farming systems.

110 For example, on the rise of sustainability certification and quality standards, Bush et al.

111 (2013) argue that while such schemes contribute towards the development of more

112 sustainable production, they have significant limitations due to the complex, context-

113 dependent social issues concerning aquaculture production, which are often overlooked. As a

114 result, many small-scale producers are excluded from these strategies due to, for example, the

115 costs or resources needed to follow the standards (Kusumawati et al., 2013), and so they are

116 often pushed out of global value chains (Bush et al., 2013). Second, there are important gaps

117 in understanding of behaviour among aquaculture producers at the farm-level regarding their

118 production intensity (Bush et al., 2010). Actions taken by producers affect social, economic,

119 and ecological conditions and can thus influence the overall sustainability of aquaculture

120 production. A better understanding of farmer behaviour in relation to their production

121 intensity is therefore central for designing measures that can effectively promote more

122 sustainable aquaculture (Bush et al., 2010).

123 In policies such as the above-mentioned sustainability standards, as well as in

124 research, shrimp aquaculture production intensity is often approached as a technical issue.

125 Yet, shrimp farms are shown to be embedded within a socio-economic landscape

126 (Vandergeest et al., 2015; Bush et al., 2010; Joffre et al., 2015, Bottema et al., 2018). Thus,

127 we hypothesize that levels of production intensity also correspond to different farm socio-

128 economic profiles that are not captured by technical indexes alone. Production intensity

129 should be considered in terms of a combination of technical indices of production embedded

130 within a broader socio-economic context. To reiterate: consideration of the complexity of

131 shrimp farmer behaviour and the wider socio-economic perspective of aquaculture

132 production matters when we think about promoting sustainability through certification

133 standards or other measures: standards may fail because they only take the technical aspects 
into account and fail to appreciate the socio-economic context in which those technical aspects are embedded (Kusumawati et al., 2013; Bush et al., 2013; also see Bottema et al.,

136 2018).

137 This study builds on earlier literature on farmer behaviour related to shrimp farming.

138 It applies the integrative agent-centred framework (Feola and Binder, 2010) to examine

139 drivers influencing shrimp farmer behaviour in relation to production intensity along the

140 eastern coast of the Gulf of Thailand, and its embeddedness in the wider socio-economic

141 context of shrimp farming households. The study was guided by the following two questions:

142 i) which socio-economic factors are related to distinct levels of shrimp farming intensity?,

143 and specifically, ii) which socio-economic factors matter in the decision to adopt a certain

144 level of production intensity?

145 The paper continues with an overview of shrimp farming in Thailand and its

146 relevance in relation to the above research gaps, and a brief overview of the study site. We

147 then bring together literature on the characterisation of shrimp farming intensity types and

148 farmer behaviour. This is followed by an overview of the research methodology and

149 presentation of the results from the case study. Finally, we discuss the key findings in relation

150 to the wider aims of the study.

\subsection{Shrimp aquaculture in Thailand}

Shrimp farming has been a traditional livelihood practice on coastal landscapes in

154 Thailand for centuries, but the character of coastal shrimp culture has changed dramatically over the past half century. Production of Penaeid shrimps, which account for around $80 \%$ of total shrimp production, has increased rapidly, from less than 24, $000 \mathrm{t}$ in 1950 to over 600 , $000 \mathrm{t}$ in 2012 (FAO, 2016b; Figure 1), with production from around 23, 800 shrimp farms along the coast (Department of Fisheries, 2018). However, total shrimp production dropped from over 600, $000 \mathrm{t}$ in 2012 to 325, $000 \mathrm{t}$ in 2013 (FAO, 2016b). This was the latest of many abrupt social-ecological dynamics: boom and bust periods driven by disease epidemics in cultured shrimp (Flegel, 2012; Leaño and Mohan, 2012), coupled with negative biophysical changes and ecological feedbacks, and a year-on-year drop in market price for shrimp (Lebel et al., 2002; Hall, 2011b; Huitric et al., 2002; Barbier and Cox, 2004; Piamsomboon et al., 2015).

Shrimp farming in Thailand has previously been characterised as being very intensive compared to other Southeast and South Asian countries (Lebel et al., 2002; Kumar and Engle, 
2016). However, aquaculture practices have been changing rapidly (Henriksson et al., 2015), and currently there is a diversity of farms of different sizes that operate in the landscape at different production intensities side-by-side. This present research therefore captures current shrimp farming diversity in the face of this rapid change and aims to better understand the socio-economic landscape of shrimp production systems.

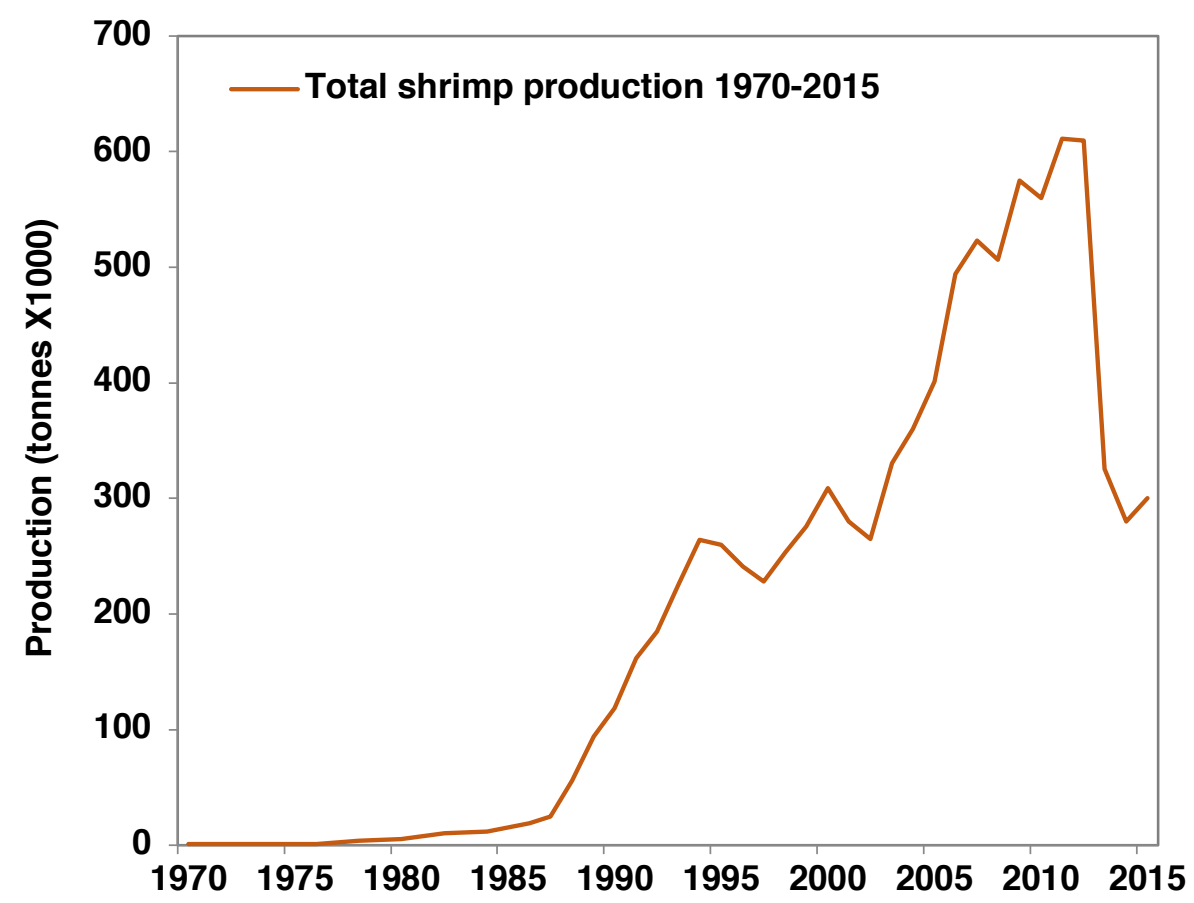

173

174

175

176

177

178

179

180

181

182

183

184

185

186

188 187 largest shrimp-producing provinces in Thailand (Hazarika et al., 2000; Department of

Figure 1. Production of cultured brackish water shrimp in Thailand from 1970 - 2015. Source: FAO FishStatJ.

This study was conducted in the sub-districts of Khlung and Laem Sing, Chanthaburi Province, on the eastern coast of the Gulf of Thailand $\left(12.61^{\circ} \mathrm{N}, 102.10^{\circ} \mathrm{E}\right.$; Figure 2$)$. The coastline of Chanthaburi stretches $68 \mathrm{~km}$ across four coastal districts; Na Yai Am, Tha Mai, Laem Sing, and Khlung. The region is characterized by its diversity of coastal habitats, including extensive seagrass beds, tidal mudflats, and mangrove forests (Janetkitkosol et al., 2003). However, large areas of mangrove forest were cleared and converted in Chanthaburi during the 1980s and 1990s to make space for aquaculture, with remaining mangroves only occurring in narrow fringes. Behind the mangrove fringe, there are many shrimp farms, rice fields, and fruit orchards.

86 Chanthaburi is a relevant area for this study because for decades it has been one of the 
190 (Piamsomboon et al., 2015).
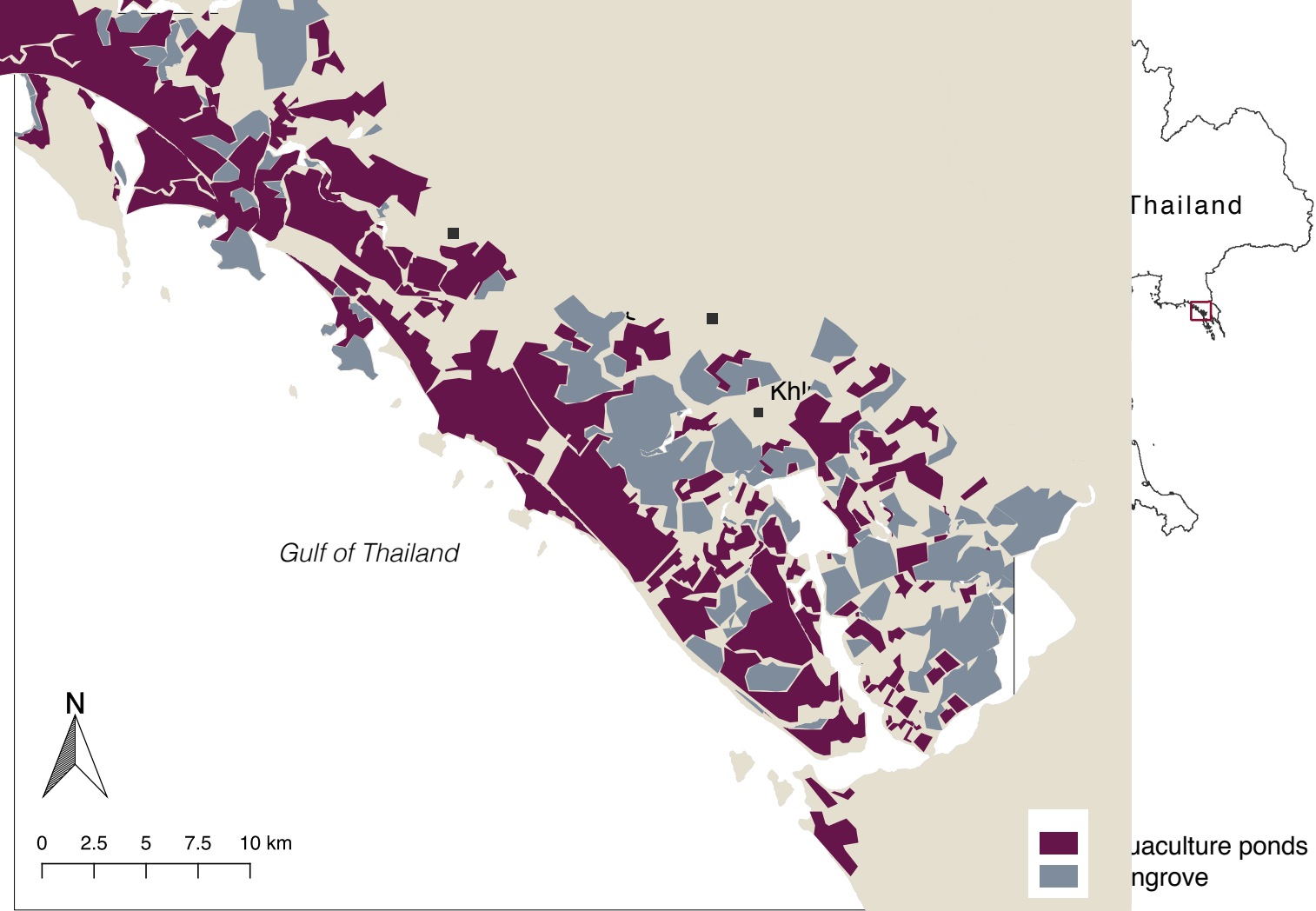

Figure 2. Map showing the study area location in the Districts of Laem Sing and Khlung, Chanthaburi Province, on the Gulf of Thailand coast.

Intensive shrimp culture along Chanthaburi's coastline began in the 1980s and expanded at a dramatic rate through the 1990s and 2000s (Hazarika et al., 2000). In 2012, there were around 2120 shrimp farms in Chanthaburi, covering 6758.72 ha in area and producing over $60000 \mathrm{t}$ of shrimp (Department of Fisheries, 2018). Two Penaeid shrimps (Litopenaeus vannamei (Whiteleg shrimp) and Penaeus monodon (Black tiger shrimp)) are the main cultured shrimp species in the region, with $L$. vannamei accounting for over $80 \%$ of total shrimp production (FAO 2016b). Shrimp production in Chanthaburi has declined sharply in recent years, mainly due to widespread viral outbreaks in shrimp, such as acute hepatopancreatic necrosis disease (AHPND) and hepatopancreatic microsporidiosis (HPM) (Putth and Polchana 2016), and subsequent global shrimp price volatility has permitted increased production and export from other countries such as China, Indonesia, and Vietnam 
(Wanasuk and Siriburananoon, 2017). In Chanthaburi, shrimp production dropped from around $61500 \mathrm{t}$ in 2012 to $33900 \mathrm{t}$ in 2013. Production of shrimp remained at $33700 \mathrm{t}$ in

2112015 , indicating that the industry has not recovered in this region (Department of Fisheries,

212 2018), and many aquaculture ponds have recently been abandoned (Piamsomboon et al., 213 2015).

214 What is left from these ecological, social and economic changes is a landscape with 215 persisting environmental issues and a diversity of farming intensities and corresponding 216 livelihood strategies, including large-scale intensive shrimp farms designed to maximise 217 production, and many independent small- to medium-scale farms. Given that shrimp 218 production is highly important for economic development in Thailand, and the demand for 219 shrimp from international markets is projected to increase (FAO, 2016c), policy makers are now confronted with the challenge of directing shrimp farmers away from environmental destruction, and towards more sustainable production systems (Bush et al., 2010; Bush and

222 Marschke, 2014; Joffre et al., 2015). Following the most recent crash of the shrimp industry in Thailand in 2013, the government updated their national certification standards in an attempt to improve environmental conditions and regain credibility in the global market. However, the uptake of these new standards has been limited due to their demanding requirements, leading scholars such as Samerwong et al. (2018) to question their inclusiveness and effectiveness.

\subsection{Characterization of shrimp farming diversity}

Different shrimp culture systems can be classified based on how similar or dissimilar they are to one another with regards to one or more variables related to technical, economical, ecological, geographical, or social aspects of production (Shang, 1981). In terms of culture production intensity, global shrimp aquaculture has been characterized as either (i) extensive,

234 (ii) semi-intensive, or (iii) intensive, reflecting a scale from low to high intensity (Tidwell

235 2012). However, these classes can vary between countries and regions (Primavera, 1993, 1998; Dierberg and Kiattisimkul, 1996).

Farm intensity types are most commonly defined using technical variables related to

238 farm size, stocking density, feed rate, or rate of fertilizer application, or economic

239 performance indicators, such as yield and income (FAO, 2018; Deb, 1998; Dierberg and

240 Kiattisimkul, 1996; Islam et al., 2005; Stevenson et al., 2007; Joffre and Bosma, 2009). To

241 date, there has been a wealth of literature on technical aspects of different shrimp aquaculture 
systems, in terms of quantitative descriptions of farm size, pond management methods, resource use, production outputs, and economic analysis (for example, Stevenson et al., 2007;

244 Kongkeo, 1997; Boyd et al., 2016, 2017, 2018; Boyd and Engle, 2017; Engle et al., 2017; Thakur et al., 2018; Islam et al., 2005). Technical analysis at the farm-level is important because it derives data which can be used to assess and reduce negative impacts of aquaculture and to guide more sustainable management practices (Boyd et al., 2017). In a farm-level survey from Thailand and Vietnam, for example, Boyd et al. (2017) concluded that, per ton of shrimp produced, intensive shrimp production systems are more efficient, use fewer resources, and result in less impact on the environment compared to more extensive shrimp production systems.

On the other hand, however, classifying culture systems using technical variables alone has its limitations. Firstly, it is difficult to classify polyculture systems based on production indices such as yield and feed rate because different species have different growth rates and feeding behaviour. In addition, farm size, which is sometimes used in classification criteria, does not consistently relate to production intensity because small farms and large farms can be managed at a similar level of intensity (Vandergeest et al., 1999; Engle et al., 2017). Furthermore, while the social-ecological costs of aquaculture have been well documented (Primavera, 1993, 1997), typologies based on technical variables do not account for the social and ecological factors influencing production intensity. Technical indices of production should therefore be complemented with information on the socio-economic context of production (Bush et al., 2013).

\subsection{Shrimp farmer behaviour}

To be able to attempt to steer the sector towards environmentally, economically and socially sustainable configurations, it is important to understand the decisions behind the diversity of farm intensities (e.g. see Bush and Marschke, 2014; Bush et al., 2010; Joffre et al., 2015b, 2019; Nguyen et al., 2018). Shrimp farmers are key actors within the system, therefore a comprehensive understanding of shrimp farmer behaviour ${ }^{1}$ is crucial for guiding pathways towards sustainability (Bush et al., 2010).

A series of social, ecological, epidemiological, and regulatory factors have been

272 shown to influence the behaviour of aquaculture producers regarding their production system

273 and farm management (Joffre et al., 2015; Ahsan and Roth, 2010; Bush and Marschke, 2014;

274 Ha et al., 2012a; 2012b; Kusumawati et al., 2013; Tendencia et al., 2013). At the macro- 
scale, Hall (2004) discusses the social processes that have influenced shrimp farmer behaviour at the regional level across countries in Southeast Asia, namely; 1) government programs and State support for shrimp farming expansion in Thailand and Indonesia, 2) corporate involvement in training, research and the building of farm infrastructure (such as Charoen Pokphand Group (C.P.) in Thailand), 3) the role of collective farmer action to reduce problems, such as regulating water systems in Thailand and Indonesia, and 4) the influx of new shrimp producers in Java which destabilized traditional farm systems.

At the farm-level, much of the research on aquaculture farmer behaviour to date has focused on risk ${ }^{2}$ perception and management, for example in relation to disease or climaterelated risks (Chitmanat et al., 2016; Lebel et al., 2016; Lebel and Lebel, 2018). In Denmark, for example, Ahsan and Roth (2010) identify that mussel farmers perceive and manage risks based on a combination of market factors (future price and demand for mussels), regulatory drivers (changes in government regulations), and bio-physical factors (weather and water conditions). Lebel et al. (2016) show that fish farmers in northern Thailand adopt short-term and medium-term adjustments to production to manage climate-related risk, such as seeking new information, and altering aeration, feeding rate, and stocking.

Other studies of aquaculture farm-level behaviour explore how producers collaborate in relation to risk perception, attitude and adoption (Ahsan, 2011; Joffre et al., 2018, 2019; Le Bihan et al., 2013). Some studies (Bush et al., 2010; Joffre et al. 2015; Bottema et al., 2018) explore shrimp farmer social structures in relation to the embeddedness of farms within a landscape, and how the extent to which farms are integrated into the landscape depends on both physical and social factors. Bush et al. (2010) for example, suggest that aquaculture farmers operating intensive 'closed' systems are less likely to adopt collective strategies for risk management compared to farmers operating extensive 'open' systems, who are more likely to self-organise. In contrast, Bottema et al. (2018) compare stocking behaviours and risk management strategies across two shrimp farm intensity types ('closed' intensive shrimp and grouper farmers in Thailand and 'open' integrated mangrove shrimp (IMS) and extensive shrimp farmers in Vietnam), and explore how individual aquaculture farmers interpret and manage environmental risks and how their ability to deal with risk relates to farmer-farmer social relations. Bottema et al. (2018) show that collective action between farmers to mitigate risks depends on shared social experiences.

Other literature explores the influence of policy and risk perception on the adoption of certain aquaculture farming practices, such as those aimed at conservation or climate change mitigation (Joffre et al., 2015, 2018; Nguyen et al., 2018). For example, studies on shrimp 
producers have looked at factors influencing the adoption of more 'mangrove-friendly' integrated mangrove-shrimp systems (IMS). In Vietnam, for instance, Joffre et al. (2015) identified that shrimp farmers shift from extensive production systems to IMS systems based on a combination of drivers which influence farm profitability and disease risk, such as biophysical drivers (the role of mangroves in pond management) and those related to the value chain and regulatory framework. Nguyen et al. (2018) explored factors influencing the adoption of IMS systems among shrimp farmers in Vietnam, which they relate to social dynamics such as learning through various media.

While this literature has contributed importantly to the understanding of aquaculture and aquaculture producers, questions still remain as to how individual decisions are made on the micro-scale, across different shrimp farming intensities in Thailand. In particular there are gaps in knowledge of how internal social and psychological processes, such as expectations, risk perception and subjective culture, interact with external technical, biophysical, and economic factors to influence shrimp aquaculture adoption behaviour in Thailand.

This study therefore builds on findings from other contexts and countries by analysing shrimp farming diversity along the coast of Thailand with the aim to understand the factors involved in farmer behaviour in relation to production intensity, including technical, social, economic and ecological drivers.

In sum, the case of Thailand is illustrative of a situation in which (i) there is diversity of farming intensities, (ii) policy has had difficulties to promote sustainable aquaculture, also because (iii) there is a knowledge gap in understanding farmer behaviour in relation to production intensity.

\section{Materials \& methods}

\subsection{Data collection and theoretical framework}

Exploratory field work was first implemented in October 2016, where a series of semi-structured interviews were conducted with stakeholders from the local to national scale. These interviews helped gain background information on current and historical shrimp farming patterns, and the scale of shrimp farming in Chanthaburi Province. Each of the interviewees had knowledge of the study area due to their occupation and/or place of residence. Interviewees included private individual shrimp farmers $(n=12)$, a local shrimp farming cooperative official, village heads $(n=2)$, Provincial representatives from the local 
government Mangrove Management Unit $(n=2)$, and representatives from the government Department of Marine and Coastal Resources in Bangkok $(n=6)$.

Following exploratory field work, the integrative agent-centred (IAC) framework

344 (Feola and Binder, 2010) was used as a basis for designing a structured survey to collect semi-quantitative data for a range of explanatory variables that potentially drive shrimp farmer behaviour in Chanthaburi Province. The IAC framework's general components (Figure 3) were first associated to the variables which were potentially influencing the studied behaviour. Such association was based on a literature review and the knowledge of the study area gained through the exploratory field work. The variables were then operationalized to be measured through semi-structured interviews (Supplementary Material).

The adoption of behavioural theory was consistent with the theoretical approach which is most commonly adopted in the aquaculture literature (see literature review above). In addition, a focus on behaviour maintains deliberate decisions at the forefront of the analysis, in contrast to competing approaches such as livelihood or social practice theory; we considered a focus on deliberate adoption decisions to be essential for the present study.

Moreover, while the IAC framework allows to maintain such focus on farmer decisions, it also allows to situate them in the wider socioecological context (Feola and Binder, 2010). Thus, this framework responds to some common limitations of behaviour frameworks, and particularly (i) the lack of an explicit and well-motivated behavioural theory; (ii) the lack of an integrative approach (i.e. one which includes a diverse range of psychological, social and economic factors); and (iii) the inability to capture feedback processes between agents' behaviour and system's dynamics (Feola and Binder, 2010). As such, the IAC framework enabled us to investigate farmer adoption behaviour as it is embedded in a particular socioecological context which includes social networks and power relations, and in the face of cross-scale/-level pressures which vary over time, such as those observed in Chanthaburi Province (see Introduction).

Finally, the IAC framework has previously been fruitfully used to study farmer behaviour in relation to production intensity in agricultural systems (Feola and Binder 2010; Feola and Binder 2010b) and was thus deemed suitable for supporting the research design for this study. The IAC framework is based on: (i) an explicit and well-motivated behavioural theory; (ii) an integrative approach; and (iii) feedback processes between agents' behaviour and system's dynamics. The questions in the survey corresponded to different classes of

373 behavioural drivers outlined in the IAC framework (Figure 3). These included: Contextual

374 factors (i.e. facilitating conditions or barriers), Habit (the frequency of past behaviour), 
375 Expectations (beliefs about the outcomes, their probability and their value), Subjective

376 culture (social norms, roles, values), and Affect (the feelings associated with the act). Each of

377 the behavioural drivers were measured through one or more questions in the survey (see

378 Supplementary Material).

379

380

381

382

383

384

385

386

387

388

389

390

391

392

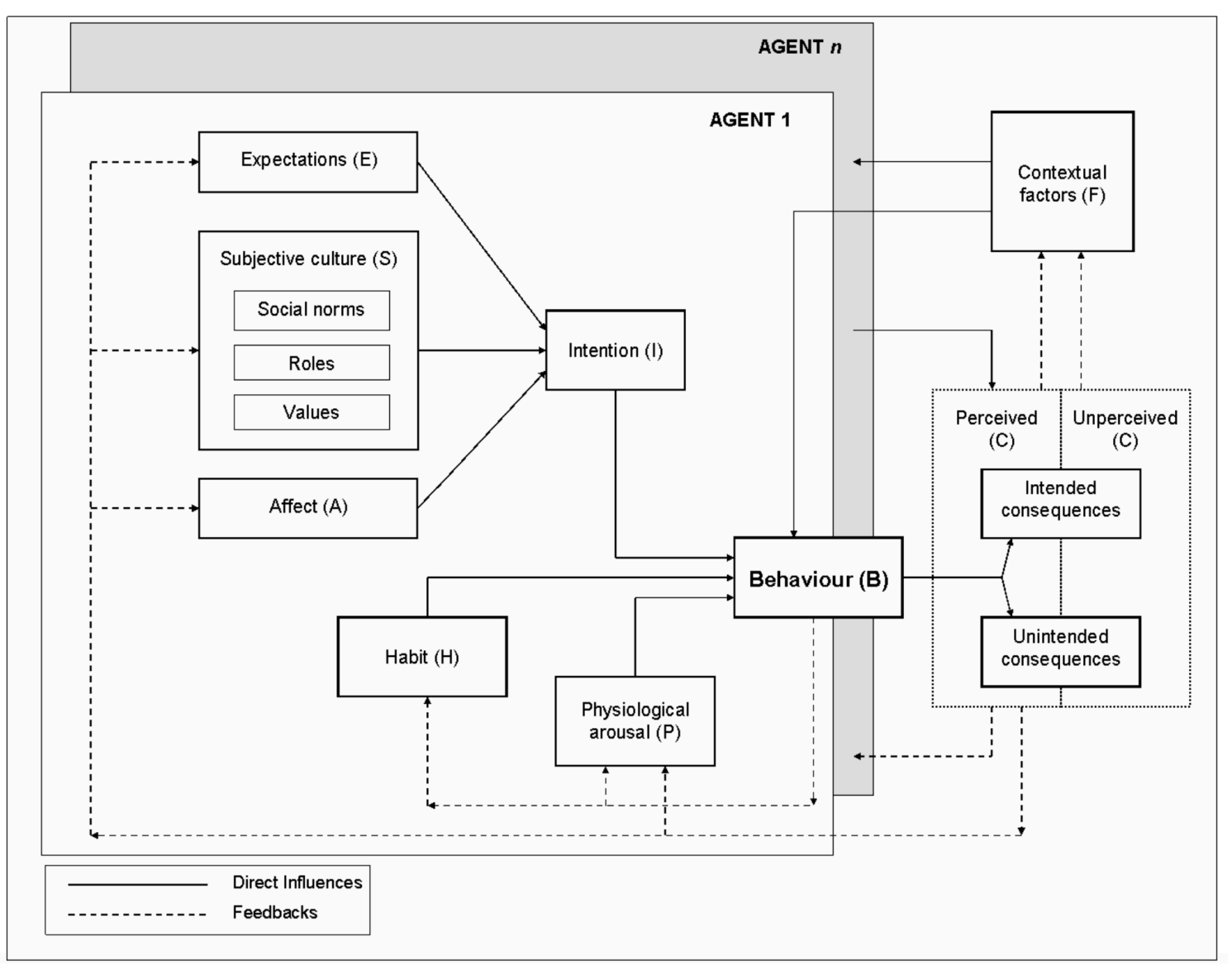

Figure 3. The IAC Framework (Feola and Binder, 2010).

To enable consistency in the data across study sites of Khlung and Laem Sing, and to make the timeframe as close as possible to the survey time, the questions referred to specific timeframes of either one production cycle, one year, or two years, as relevant depending on the question. The survey design aimed to generate data from shrimp farmers working across a range of shrimp farm intensity types, from low-intensity traditional polyculture systems to more technologically advanced intensive shrimp monoculture, so that data could be compared across farm management intensity categories.

Fieldwork was conducted between February and May 2017. A total of 102 shrimp farmers and farm workers were surveyed. Respondents were selected to provide a wide 
geographical cover across the survey area, and a relevant sample of the shrimp farmers in the area, avoiding biases associated with particular locations and shrimp farm sizes. Respondents were sought systematically by visiting farms and houses along the coastal Province area, and through snowball sampling (Goodman, 1961). All surveys were conducted on an individual shrimp farmer basis to ensure that the responses reflected personal information. In 6 of the 102 cases, the owner of the shrimp farm did not live on the farm, or was only present occasionally, and therefore the farm operator was interviewed instead. These surveys were subsequently removed from the sample.

\subsection{Data analysis}

In order to characterize the socio-economic context of farmers farming at different levels of intensity and to be able to then compare the behaviour of shrimp farmers across farm intensity types, survey respondents were first classified into farm intensity types based on technical similarity within groups with regard to production intensity. Survey data were used to characterize the socio-economic (including demographic and market related) factors associated with each level of farming intensity (Table 1). Three production intensity proxy variables were used to define farm intensity type: 'shrimp yield (kg ha crop)', 'shrimp stocking density $\left(\mathrm{PL} \mathrm{m}^{2}\right)$ ', and 'number of shrimp crops produced per year'. The grouping of farms under each of the three key variables was based on FAO farm type classifications (extensive 'low intensity', semi-intensive 'medium intensity', and intensive 'high intensity') for the two principal brackish water shrimp species cultured in the study region, P. monodon (Black tiger shrimp; FAO, 2018c) and L. vannamei (White shrimp; FAO, 2018b). We chose to classify shrimp farms in the present study based on FAO farm type classifications because this is a globally standard classification system which is recognised in aquaculture policy. Therefore, through our subsequent analysis of adoption behaviour and socio-economic differences, we would be better able to demonstrate that groups of aquaculture farmers are more diverse than considered in current aquaculture policy.

For the three production intensity proxy variables, the minimum and maximum values for each species were first calculated separately for each individual pond. Minimum and maximum values were then assigned to one of the three production intensity classifications ('low', 'medium', or 'high' intensity). Where minimum and maximum values fell between two intensity categories (for example, minimum = 'medium intensity' and maximum = 'high intensity'), then the mean of the variable was used. If ponds of a farm fell in more than one of 
427 the intensity categories (for example, 5 ponds for 'high intensity' and 1 pond for 'medium 428 intensity'), then the farm was allocated to the modal farm type (i.e. 'high intensity' in the 429 example).

$430 \quad$ Following identification of the three farm intensity types, survey responses which

431 related to the internal and external behavioural drivers (Figure 3) were compared between

432 farm intensity types. Where differences in responses were found between farm intensity

433 types, the significance level of the difference was statistically tested using the non-parametric

434 Kruskal-Wallis (K-W) H test, followed by the Dunn post hoc multiple comparisons test,

435 where appropriate. Drivers that were found to be statistically different were treated as the

436 determinants of adopting a particular shrimp farming production intensity. All statistical

437 analysis was performed using the software R. Differences at the 0.05 level were considered

438 significant.

439

440 3. Results

441 3.1. Shrimp farm intensity types

442 This study shows that three distinct farmer profiles /socio-economic configurations 443 and livelihood structures correspond to each distinct production intensity level (low, medium, 444 and high). Descriptive statistics on the different socio-economic-technical variables of farm 445 intensity types are presented in Table 1. 
447 Table 1. Descriptive statistics on different socio-economic-technical variables of farm intensity types, including shrimp farmer demographic variables, technical 448 (production related) variables, labour/farm organisation variables, and disease occurrence across the three sampled farm intensity types (low, medium, and high).

449 Values are mean \pm 1 SD and range in parenthesis.

\begin{tabular}{|c|c|c|c|c|}
\hline \multirow[b]{2}{*}{ Type of factors } & \multirow[b]{2}{*}{ Variable } & \multicolumn{3}{|l|}{ Farm intensity type } \\
\hline & & Low & Medium & High \\
\hline \multirow[t]{10}{*}{ Demographic } & Number of farmers & 50 & 27 & 19 \\
\hline & Gender (\% of farmers): & & & \\
\hline & Male & 64 & 78 & 100 \\
\hline & Female & 36 & 22 & 0 \\
\hline & Age & $55 \pm 10(29-78)$ & $50 \pm 10(28-72)$ & $49 \pm 12(31-70)$ \\
\hline & $\begin{array}{l}\text { Highest education level (\% of } \\
\text { farmers): }\end{array}$ & & & \\
\hline & None & 18.0 & 0.0 & 0.0 \\
\hline & Primary & 54.0 & 67.0 & 68.4 \\
\hline & Secondary & 20.0 & 19.0 & 10.5 \\
\hline & College/university & 8.0 & 15.4 & 21.1 \\
\hline \multirow[t]{6}{*}{ Socio-economic } & Farm ownership status (\% of farmers): & & & \\
\hline & Owner & 76.0 & 78.0 & 63.2 \\
\hline & Leased & 6.0 & 22.0 & 36.8 \\
\hline & Government entitlement (tenure) & 18.0 & 0.0 & 0.0 \\
\hline & Farm operating years & $32 \pm 17(6-100)^{\star * *}$ & $17 \pm 9(1-40)$ & $17 \pm 12(3-50)$ \\
\hline & Farm helpers (persons/ha) & $0.3 \pm 0.3(0-1.3)^{* *}$ & $1.4 \pm 2.2(0-10.9)$ & $2 \pm 2.5(0-10.4)$ \\
\hline \multirow{5}{*}{$\begin{array}{l}\text { Technical (farm and } \\
\text { ponds) }\end{array}$} & Farm area (ha) & $11.2 \pm 7.8(1.6-38.4)$ & $2.9 \pm 3.6(0.2-16.0)$ & $3.8 \pm 4.8(0.4-16)$ \\
\hline & Total pond area (ha) & $10.9 \pm 8.0(1.0-38.4)^{\star \star \star}$ & $2.2 \pm 2.8(0.2-12.8)$ & $2.6 \pm 2.7(0.4-9.4)$ \\
\hline & Number of ponds & $1.2 \pm 0.9^{* *}$ & $4 \pm 7(1-40)$ & $5 \pm 5(1-16)$ \\
\hline & Average pond size (ha) & $10.3 \pm 7.1(0.5-32)^{\star \star \star}$ & $0.56 \pm 0.23(0.24-1.12)$ & $0.56 \pm 0.17(0.32-0.86)$ \\
\hline & Species cultured (No.) & $4 \pm 1(1-5)^{\star \star \star}$ & $1.1 \pm 0.5(1-3)$ & $1 \pm 0.2(1-2)$ \\
\hline Technical (production) & L. vannamei yield (mean) & $28 \pm 33-36 \pm 41^{\star \star \star}$ & $2288 \pm 2144-2587 \pm 2256^{\star \star \star}$ & $6119 \pm 3793-6767 \pm 3928^{* * *}$ \\
\hline
\end{tabular}




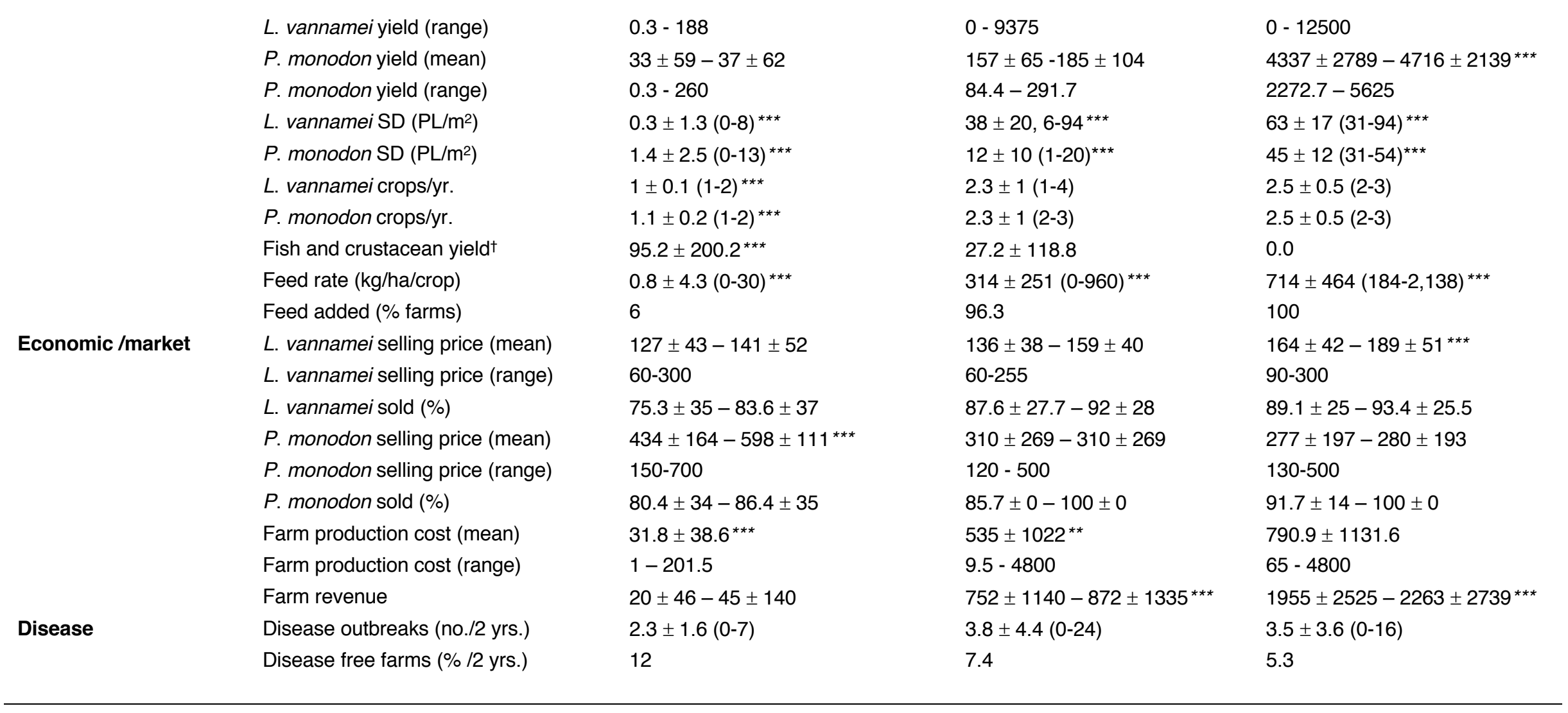

Significant difference between farm intensity types: ${ }^{* *} 0.001,{ }^{* *} 0.01$ (Kruskal-Wallis test with the Dunn post hoc test).

Yield is measured in $\mathrm{kg} / \mathrm{ha} / \mathrm{crop}$, Value is measured in THB/kg, Farm production costs and revenue is presented in 1,000THB per crop. SD $=\mathrm{Stocking}$ density.

tincluding fish $\mathrm{sp} ., \mathrm{crab} \mathrm{sp}$, and shrimp species other than $P$. monodon and $L$. vannamei. 
Farm intensity type 1: 'low intensity'. Low intensity farms comprised the largest sampled group (52\% of the sample). On average, these farms had been operating for significantly longer than medium and high intensity farm types $(p<0.05)$. Around one fifth of the farms were located on government owned land which was allocated for use under the government's 'Entitlement' policy. Under this policy, abandoned or reclaimed intensive shrimp farms built in areas previously occupied by mangrove forest are allocated to local people for aquaculture use. These farms were located within government conservation areas where restrictions are made on the use of machinery for pond maintenance. Without maintenance, the old pond dikes can gradually erode, resulting in one large aquaculture area, rather than a number of individual ponds. As a result, mean pond size was significantly larger by around 4-5 times compared to other farm intensity types $(p<0.001)$, and the number of ponds on these farms was significantly lower $(\mathrm{p}<0.05)$. Family members normally assist with day to day running of low intensity farms, and additional labour is hired only for less frequent work, such as pond harvesting. As a result, the labour input per hectare of low intensity farms was significantly lower than other farm intensity types $(p<0.001)$.

Almost $100 \%$ of the low intensity farms were polyculture systems with around $60 \%$ of mean total aquaculture yield from culturing species of fish, crab, and other less commercial important shrimp species. The mean number of aquaculture species cultured was significantly higher than on other farm intensity types $(p<0.001)$. Furthermore, stocking density of $\mathrm{L}$. vannamei and P. monodon, and the mean number of crops of these species per year, was significantly lower than on other farm intensity types $(p<0.001)$.

Most of the low intensity farms produced shrimp on the basis of natural productivity in the pond. The methods practiced are typical of extensive polyculture production, whereby shrimp, along with fish and mud crab (Scylla serrata) species, enter the ponds through natural tidal inflow to the ponds. Wild species trapped in the ponds are raised with little to none commercial feed inputs, and the produce is harvested frequently throughout the year when they have attained a marketable size. As a result, average production costs on low intensity farms were significantly lower than on other farm intensity types $(p<0.001)$. Furthermore, only $6 \%$ of farmers reported using commercial feed, and this was at rates significantly lower than other farm intensity types $(p<0.001)$. around average across farm intensity types. Of particular note, however, was that the mean selling price of $P$. monodon was significantly higher compared to medium and high intensity farms $(p<0.001)$. This is likely to be because the shrimp are growing in larger, less densely 
stocked ponds thus enabling them to grow to a larger size, and because low intensity farmers select larger, more valuable shrimp to sell.

Some of the low intensity farmers reported being constrained by environmental change and environmental quality. For example, due to problems such as pond dike erosion and increasing costs of pond maintenance. Because one fifth of these farms are located within government conservation areas, farmers are faced with production constraints and fluctuations in the productive areas. Around $75 \%$ of low intensity farmers reported that they had observed erosion to the dykes of over $50 \%$ of ponds on their farm. As the ponds gradually fill in with sediment, the total surface area of the farm reduces.

Shrimp farming was not the primary income source for the majority of low intensity farmers. Only $40 \%$ of farmers stated that all or most of their income is from shrimp farming, and $48 \%$ stated that very little or none of their income is from shrimp farming. Some of these farmers operate on a part-time or casual basis, sometimes for subsistence use only, or to provide supplementary income i.e. farmers have primary employment elsewhere but keep a small number of ponds active but on a less intensive scale.

Around $73 \%$ of the low intensity farmers reported that they had reduced the amount of shrimp produced in the past two years, $12 \%$ had increased the amount, and $16 \%$ had not changed the amount produced. $49 \%$ of farmers stated that they had reduced the number of species produced and $8 \%$ had increased the number of species.

Farm intensity type 2: 'medium intensity'. Medium intensity farms comprised 28\% of the total sample. Farm operating years, mean pond size, and the number of hired labour used on these farms was similar to that observed on high intensity farms $(\mathrm{p}>0.05)$. Whereas, pond stocking densities of both L. vannamei and P. monodon were significantly higher than on low intensity farms but significantly lower than on high intensity farms $(p<0.001)$. Furthermore, production of $P$. monodon was significantly lower than on high intensity farms $(p<0.001)$. The majority of medium intensity farms specialised in the production of $L$. vannamei and, although mud crabs and fish species were sometimes cultured as secondary species, the total yield from species other than P. monodon and L. vannamei accounted for less than $1 \%$ of the total production, which was significantly lower than that produced on low intensity farms $(p<0.001)$. On some polyculture farms, farmers reported that they stock higher-value shrimp and crab species, but fish that are raised were recruited from the natural tidal waters. 
523 Production costs on medium intensity farms were considerably variable, reflecting the

524 heterogeneity in management within this farm intensity type. Use of commercial feed was at

525 rates significantly higher than low intensity farms $(p<0.001)$, but significantly lower than on

526 high intensity farms $(p<0.01)$. Whereas, farm return on medium intensity farms was

527 significantly lower than high intensity farms $(p<0.001)$, but not significantly different to low

528 intensity farms $(p>0.05)$. Around $70 \%$ of medium intensity farmers stated that all or most of

529 their income was from shrimp farming, and 20\% stated that very little comes from shrimp

530 farming. Medium intensity farms have had the highest number of disease outbreaks over the

531 past 2 years. However, disease occurrence was not significantly different across all farm

532 intensity types $(p=0.09$ ). Around $46 \%$ of medium intensity farmers reported that they had

533 reduced the amount of shrimp produced in the past two years, 30\% had not changed the

534 amount, and 23\% had increased the amount. 27\% had increased the number of species

535 produced, $11 \%$ had reduced the number of species, and $61 \%$ had not changed the number of

536 species produced.

537 Farm intensity type 3: 'high intensity'. High intensity farms comprised the smallest

538 sampled group ( $20 \%$ of sample). These farms contained the highest average number of ponds

539 and maximum pond size did not exceed 1 ha across farms. Average farm area was slightly

540 larger than medium intensity farms but significantly smaller than low intensity farms $(p<$

$5410.05)$. Total area of ponds in use made up around $68 \%$ of total farm area. The further $30 \%$

542 comprised either ponds that were currently left unused, or ponds that were used for water

543 management, which is common practice in highly intensive shrimp farming systems.

544 Chemicals and treatment ponds were used to control water quality, and to remove predators

545 from the water before PL are stocked.

546 Almost $100 \%$ of the high intensity farms sampled were monoculture systems

547 specialising in L. vannamei production, with P. monodon being the only other secondary

548 species. Mean production and stocking densities of L. vannamei and P. monodon was

549 significantly higher compared to all other farm intensity types $(p<0.001)$. Whereas, mean

550 number of L. vannamei and P. monodon crops per year was significantly greater than low

551 intensity farms $(p<0.001)$, but similar to medium intensity farms.

552 Feed was added to high intensity ponds at rates significantly higher than other farm

553 intensity types $(p<0.001)$. The intensive shrimp farms were often linked to large shrimp feed

554 producing companies, such as C.P. (Charoen Pokphand) Group, which is one of the world's

555 leading producers of shrimp and shrimp feed and a major supplier of shrimp feed and shrimp 
post larvae (PL) to intensive shrimp farmers in the study area. On high intensity shrimp farms, the ponds were managed in a very controlled way. For example, a cycle of a specific number of days (usually 90) following feed tables to attain shrimp of a certain size and weight at the end of the crop cycle.

Like on medium intensity farms, production costs were highly variable on high intensity farms suggesting that management practices varied greatly. Although production costs were on average not significantly higher than on medium intensity farms $(p>0.05)$, high intensity farms generated significantly greater return than any other farm intensity type $(p<0.001)$. The average selling price for L. vannamei was higher than on other farm intensity types. Whereas, P. monodon produced on high intensity farms sold for a relatively low price which may reflect differences in either the quality or size of shrimp sold, or who the shrimp were sold to. Similar to medium intensity farmers, nearly three quarters of high intensity farmers stated that all or most of their income came from shrimp farming, with less than $20 \%$ stating that shrimp farming contributed very little to their total income.

Around $44 \%$ of the high intensity farmers reported that they had reduced the amount of shrimp produced in the past two years, whereas $27 \%$ said they had increased the amount of shrimp produced. $83 \%$ of high intensity farmers stated that they had not changed the number of species produced over the same period, the rest (16\%) had decreased the number of species.

\subsection{Farmer behaviour (production intensity)}

Based on the IAC framework, we understand farmer adoption behaviour (here: production intensity) as the result of decisions that are influenced by a set of internal and external, symbolic and material, individual and social factors (Figure 3). All variables considered in the IAC framework (see Supplementary Information) were tested for significance in driving behaviour, but we report here only the significant ones. This analysis helps to distinguish which factors influence the decision to adopt a certain level of production intensity.

Shrimp farmers of the three farm intensity types differed significantly in relation to eight key variables considered by the IAC framework. This included contextual (external socio-economic and production) factors (such as training received on farming practices, access to the technical equipment needed to farm shrimp intensively, proportion of total income from shrimp farming, and season-specific changes to their production), as well as 
internal factors related to subjective culture (social norms and roles) (such as what shrimp farmer believes other farmers think about their adoption of a particular production intensity, how often shrimp farmer follows advice from other farmers, pond stocking considerations, level of care for the environment, and perception of a 'good shrimp farmer'), and expectations (perceived risks associated with intensive shrimp farming). A summary of the key findings in relation to these interactions is presented below.

Contextual factors (socio-economic). We found that shrimp farmers who operated low intensity farms were less likely to have received training from private and/or government agencies, compared to high $(p=0.017)$ and medium intensity $(p=0.008)$ farmers. A significant difference was also observed in terms of technical equipment access, with a higher proportion of high and medium intensity farmers having access to equipment, compared to low intensity farmers $(p<0.0001)$. Low intensity farmers were also found to have more diverse income sources and a significantly lower proportion of these farmers relied solely on income from shrimp farming $(p=0.012)$. Whereas, farmers whose income depended $100 \%$ on shrimp farming were significantly more likely to operate high intensive farm systems $(p=$ $0.012)$.

606

607 Contextual factors (production). Medium and high intensity farmers were more likely to 608 engage in season-specific changes to their production, such as modifying shrimp stocking during the monsoon onset. A significantly higher proportion of these farmers stated season is a primary factor considered before stocking shrimp, compared to low intensity farmers (high:

$611 p=0.020$, medium: $p=0.025$; Figure $4 \mathrm{a}$ ). Whereas economic factors, such as production

612 costs and money available and potential loss of money were shown to be important stocking

613 considerations among low intensity farmers.

615 Subjective culture (social norms). Social dynamics, such as information networks and 616 conformity with the descriptive norm, also played a role in defining farming intensity levels.

617 For example, medium intensity farmers were significantly more likely to have received advice 618 from other shrimp farmers regarding their production $(p=0.0001)$, suggesting that other 619 farmers are a source of information to base production decisions on. On the contrary, low 620 intensity farmers appeared to have weaker social networks, that is they were significantly less 621 likely to have received advice from the government $(p=0.0001)$ or other farmers $(p=0.008)$ on their farming practices. In addition, when asked how other farmers perceive their 
623 production intensity, low intensity farmers were significantly more likely to give a neutral

624 response (i.e. not negative or positive), compared to medium $(p=0.046)$ and high $(p=0.006)$

625 intensity farmers. These findings indicate that low intensity farmers' decisions on production

626 are made on a more individual basis and are less influenced by external actors.

628 Subjective culture (roles). A sense of care for the environment among low intensity farmers

629 was reflected in the way these farmers perceived the status of a "good shrimp farmer". For

630 example, $22 \%$ of low intensity farmers considered care for the environment as a main trait,

631 and a significantly higher proportion of low intensity farmers believed that no chemical use ( $p$

$632=0.0009)$ and farming on the basis of nature $(p=0.044)$ were important characteristics

633 (Figure 4b). These findings illustrate that production decisions of low intensity farmers are in

634 part rooted in perceptions of how farming affects the natural environment. Whereas,

635 decision-making based on learning from experience was more important to high intensity

636 farmers, who were significantly more likely to regard this as characteristic of a "good shrimp

637 farmer" $(p=0.013)$.

638

639 Expectations. Farmer intensity types were also differentiated with respect to their perception

640 of the consequences of intensive farming, illustrated by differences in risk perception.

641 Although $62 \%$ of all farmers across intensity types believed disease outbreak to be a primary

642 risk factor, medium and high intensity farmers were significantly more likely to perceive low

643 quality shrimp post-larvae (PL) as a main risk (high: $p=0.012$, medium: $p=0.023$ ).

644 However, this perceived risk was not apparent among low intensity farmers. Instead, a higher

645 proportion of low intensity farmers considered high production cost to be a main risk factor,

646 indicating that their production choices could be in part based on limiting potential cost to the

647 household. The risk losing money through intensive shrimp farming was regarded highly

648 across all farmer intensity types (>75\% of farmers; Figure $4 \mathrm{c})$.

649

650

651

652

653

654

655

656 
a)

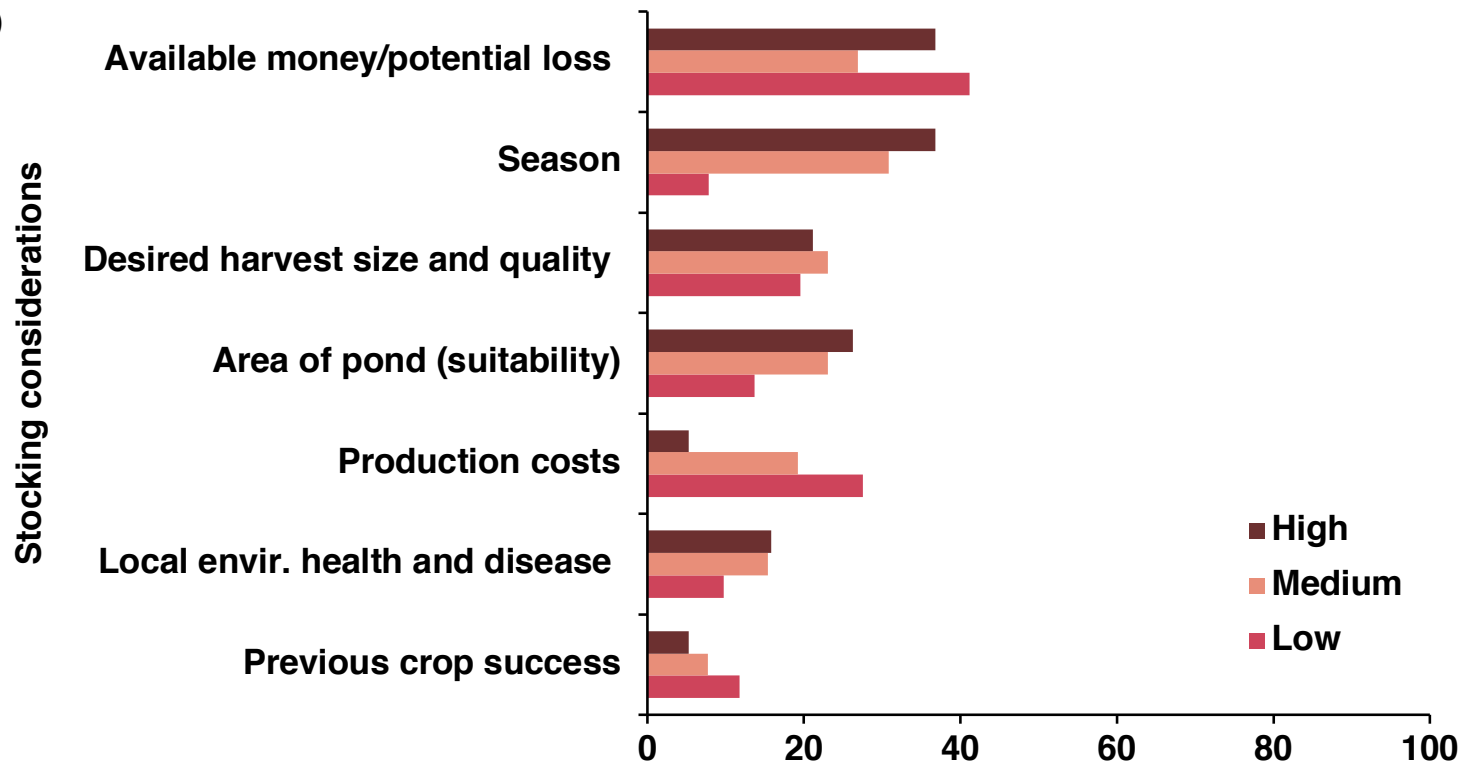

b)

No chemical use

Care for the environment

Produce by nature

Treat pond waste

Stay within budget

Learn from experience

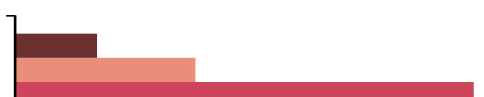

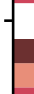

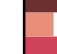

c)
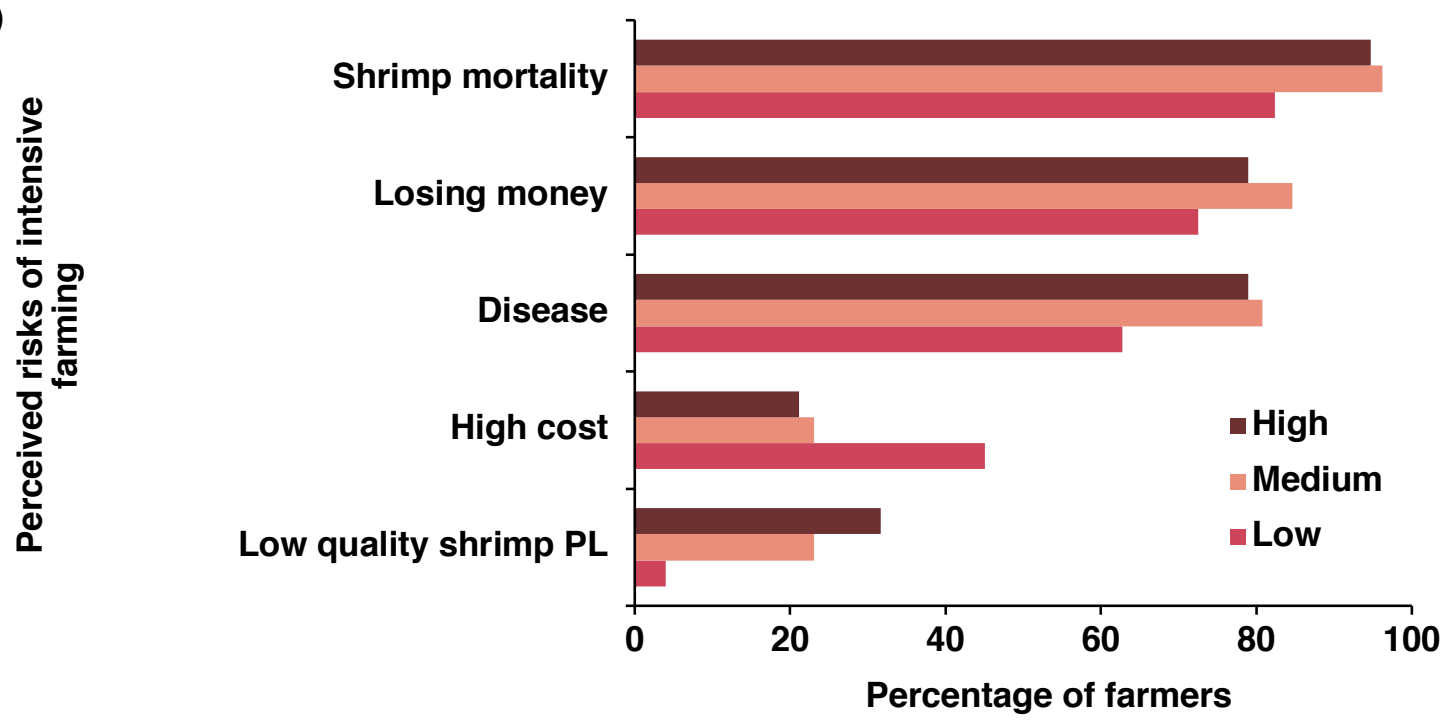

Percentage of farmers

661 Figure 4. Shrimp farmer a) pond stocking considerations, b) perceptions of a "good shrimp farmer", and

662 c) perceived risks of intensive farming. Data shows the percentage of farmers of low $(n=50)$, medium $(n=$

$66327)$ and high $(n=19)$ farm intensity type that gave each response. 


\section{Discussion and conclusions}

665

666

667

668

669

670

671

672

673

674

675

676

677

678

679

680

681

682

683

684

685

686

687

688

689

690

691

692

693

694

695

696

This study investigated shrimp farming diversity and farmer behaviour in two coastal districts of Chanthaburi Province, Thailand. The study aimed to answer two research questions: i) which socio-economic factors are related to distinct levels of shrimp farming intensity?, and specifically, ii) which socio-economic factors matter in the decision to adopt a certain level of production intensity? Here we discuss the study's findings in relation to these two questions and reflect on the implications of these findings for the promotion of sustainable shrimp farming in Thailand.

Three types of shrimp farms were identified in the study area, defined by their production intensity (low, medium, and high), and socio-economic factors. While different in their technical dimensions, this study shows that farm intensity types also differ in terms of socio-economic factors: shrimp farming intensity is associated with a combination of technical (e.g. farm area, pond size, stocking density and production), economic (shrimp selling price, production costs and farm revenue), social (e.g. farm operating years, the use of family labour, engagement in shrimp farming and with other shrimp farmers), and ecological factors (e.g. farmer reliance on natural pond productivity, and constraints brought about by environmental change and fluctuations in productive areas). However, some differences between farm intensity types are shown to be stronger than others. For example, medium and high intensity farms were more similar in terms of farm operating years, labour use, pond area, number of ponds, pond size, species cultured, and shrimp crops produced. Whereas, they were shown to be substantially different in terms of other technical production and economic/market variables, such as feed rate, shrimp selling price, and farm revenue. In addition, we demonstrate that low intensity farming is much more socio-economic and technically distinct from medium and high intensity farming related not only to stocking density, yield, and crops produced but also to variables such as labour use, species cultured and harvesting strategy. The results also demonstrate substantial within-group diversity in medium intensity production itself related, for example, to number of ponds, fish and crab yield, production costs, and farm revenue. We therefore suggest that future studies consider applying multivariate techniques such as cluster analysis to identify a more detailed division of shrimp farm intensity types than the one adopted in this study (e.g. see Johnson et al., 2014; Kumar and Engle, 2017; Engle et al., 2017). than a technical decision, but instead farms and farmers are embedded within a broader socio- 
economic context. This supports earlier work by scholars such as Bush et al. (2010), Joffre et al. (2015), and Bottema et al. (2018), who have explored shrimp farmer social structures in relation to the embeddedness of farms within a landscape. Bush et al. (2010) and Vandergeest et al. (2015), for example, argue that a farms' socio-economic embeddedness relates to its level of physical interaction with the surrounding environment, which influences farm management decisions (Waite et al. 2014).

Shrimp farming in Thailand has previously been presented as being very highintensive production orientated (Lebel et al., 2002; Kumar and Engle, 2016), with considerably less diversity, compared to other Southeast and South Asian countries like Vietnam, Bangladesh or Indonesia, where there is greater dependence on varying degrees of lower-intensity extensive production systems (Belton and Azad, 2012; Jespersen et al., 2014; Joffre et al., 2015; Nguyen et al., 2018). In 2002, for instance, Lebel et al. (2002) described Thailand's shrimp farming industry as being dominated by high intensity farming systems. Yet, this study found that a large proportion of shrimp farms in Chanthaburi were low intensity farms, indicating that shrimp farming in this area has evolved over the past 15 years towards more lower intensity production. Our findings may support a recent study by Engle et al. (2017), who report that shrimp farming in Thailand lacks long-term profitability due to economic losses resulting from disease epidemics coupled with increasing land and capital costs.

This study also enabled identification of a number of external and internal socioeconomic factors related to the decision to adopt a certain level of production intensity. This included external contextual factors, such as training received on farming practices, access to technical equipment, proportion of total income from shrimp farming, and season-specific changes in production, along with internal factors, such as expectations (risk perception) and subjective culture (e.g. how often shrimp farmers follow advice from other farmers, level of care for the environment, and perceived traits of a 'good shrimp farmer'). Two of these factors warrant further discussion.

\subsection{Social networks and risk management}

First, high intensity farmers were not likely to engage in farmer-farmer interactions. This supports previous work by Bush et al. (2010) who suggest that aquaculture farmers operating intensive 'closed' systems are less likely to adopt collective strategies for risk management compared to farmers operating extensive 'open' systems, who are more likely to 
self-organise. In contrast, social networks and farmer to farmer interactions were more

731 frequent among medium intensity farmers. Collaboration among medium intensity farmers appeared to be important for risk management and building trust, as the following statement

733 from one farmer shows, "it's important to have a good relationship with surrounding farmers

734 because sometimes they contaminate ponds". While another farmer explained that,

735 "neighbouring farmers consult with each other to solve problems together". Similarly, other studies have shown that farmer to farmer interactions can influence decisions on production and risk management (Adger, 2003; Bottema et al., 2018; Hoque et al., 2018; Ahsan, 2011; Joffre et al., 2018; Le Bihan et al., 2013), and can lead to the development of trust and the exchange of knowledge (Berkes and Folke, 2002). Bottema et al. (2018), for example, found that communication and information sharing about disease and other environmental risks among neighbouring aquaculture farmers in Thailand and Vietnam, was perceived by the farmers to be an important component of risk management.

\subsection{Economic and cultural factors}

Second, this study illustrates that a combination of economic and cultural factors matter in the decision to adopt a certain level of production intensity. For instance, among low intensity farmers, there was a sense of pride in being recognized as producers who care for the environment, and these farmers were more likely to perceive caring for the environment as a trait of a 'good shrimp farmer'. This suggests that subjective culture plays a role in the adoption of low intensity farming. Greater care for the environment among low intensity farmers, compared to high or medium intensity farmers, could be a reflection of higher dependency on a healthy natural environment, given that low intensity farming relies on natural pond productivity. On the other hand, high intensity farmers were more likely to perceive a 'good shrimp farmer' as being one who uses their own experience in farm management decisions.

Regarding economic factors, production costs and potential loss of money were shown to be particularly important stocking considerations among low intensity farmers, indicating that financial capital was a factor driving the decision to adopt low intensity production. Our results conform with another study of shrimp producers in Thailand by Engle et al. (2017), who show that the ability of farmers to shift to more intensive production practices depends on the farm's access to sufficient capital, experience, and knowledge.

762 Similarly, in Bangladesh (Bunting et al., 2017), rising costs of shrimp production and greater 
exposure to debt cycles has driven farmers away from adopting technology for intensive production.

\subsection{Policy implications}

Finally, in emphasizing the heterogeneity that exists among shrimp farms and shrimp farmer behaviours in Thailand, our analysis challenges the effectiveness and accessibility of the most recent national certification standards for aquaculture in this country (GAP-7401). Whilst these standards aim to improve the sustainability of shrimp production, through reducing production risks, and improving social and environmental conditions, they fail to recognise the diversity of the sector and the different socio-economic contexts for different levels of farming intensity, as highlighted in the present study. For many farmers, the adoption of GAP-7401 standards involves high costs and labour requirements (Samerwong et al., 2018) that do not correspond to the family-based labour model adopted by many low and medium intensity farmers, nor their socio-economic context. Even high intensity farmers, they often stated that government guidance on production was too general or difficult to follow and did not account for the variability among farming practices, and so if taken on board it was done so and adapted to their own individual context. One farmer, for instance, stated that, "there are many government regulations and they're not always realistic, so farmers have to modify them". This confirms key findings in the same region (Samerwong et al., 2018), where Thai shrimp farmers were shown to value their own experience and methods for tackling disease problems, rather than external advice, which has constrained their willingness to adhere to Good Aquaculture Practice (GAP) standards.

While we recognise that the effect of a relatively small sample size of shrimp farmers interviewed in this study is a potential limitation to fully understanding the complexity of shrimp farmer adoption behaviour, our analysis has illustrated substantial diversity among aquaculture farms and farmers in Chanthaburi and therefore makes an important contribution to the scientific and societal debate on aquaculture standards. Thus, we emphasise that national aquaculture standards should be designed to reflect the diversity needed to support such a diverse sector: to achieve sustainability in shrimp farming, policies and certification standards should be adjusted (or adjustable) to different socio-economic contexts. 
The authors thank the many shrimp farmers and community members in Chanthaburi

797 Province who we were able to interview to make this work possible. For their logistical support, the authors also thank the staff at the Department of Marine and Coastal Resources, especially Mr Chatree Maknual for general coordination of fieldwork, along with Tamanai

800 Pravinvongvuthi and Thawinee Saree. We also thank Usa Cherdchoo, Thidarat

801 Plianplaengdee, Krittika Thongyoo, and Supaporn Phongsala for their assistance with survey data gathering and translation. Additionally, we gratefully thank Joanna M Clark, Elizabeth

Funding: This work was supported by the Economic and Social Research Council [grant number ES/J500148/1], and the University of Reading.

\section{Footnotes}

1The term "behaviour" refers in this paper to an action or a series of actions. An "action", or "social action", refers to a series of acts enacted by a social actor, selected among possible alternatives, on the basis of a plan which can evolve in the course of the action itself. The social action aims at a goal, given a situation or context shared also by other actors who can react, and by norms, values, means, and physical objects, which the actor considers, to the extent he/she disposes of information and knowledge (adapted from Gallino, 1993). "Social action" and "behaviour" are distinguished from "decision-making", which refers to the cognitive "process of making a selective intellectual judgment when presented with several complex alternatives consisting of several variables, and usually defining a course of action or an idea" (from the Online Medical Dictionary: http://www.mondofacto.com/dictionary/).

2The term "risk" refers in this paper to 'a state of uncertainty where some of the possibilities involve a loss, catastrophe, or other undesirable outcome' (Hubbard, 2014).

\section{References}

Ahsan, D., Roth, E., (2010). Farmers' Perceived Risks and Risk Management Strategies in an Emerging Mussel Aquaculture Industry in Denmark. Marine Resource Economics 25 (3), 309-323.

Ahsan, D. A. (2011). Farmers' motivations, risk perceptions and risk management strategies in a developing economy: Bangladesh experience. Journal of Risk Research, 14(3), 325-349.

Alongi, D.M., (2002). Present state and future of the world's mangrove forests. Environmental Conservation, 29, 331-349.

Belhabib, D., Sumaila, U.R., Pauly, D., (2015). Feeding the poor: contribution of West African fisheries to employment and food security. Ocean Coastal Management 111, 72-81.

Belton, B, Thilsted, S.H., (2014). Fisheries in transition: Food and nutrition security implications for the global South. Global Food Security 3(1), 59-66.

Belton, B., \& Azad, A. (2012). The characteristics and status of pond aquaculture in Bangladesh. Aquaculture 358, 196-204.

Barbier, E.B., Cox, M., (2004). An economic analysis of shrimp farm expansion and mangrove conversion in Thailand. Land Economics 80(3), 389-407.

Barbier, E.B., Sathirathai, S. (eds.), (2004). Shrimp Farming and Mangrove Loss in Thailand. Edward Elgar Publishing, Cheltenham, U.K. 
Boyd, C. E., Engle, C., (2017). Resource use assessment of shrimp, Litopenaeus vannamei and Penaeus monodon, production in Thailand and Vietnam. Journal of the World Aquaculture Society 48, 201-226.

Boyd, C.E., McNevin, A.A., (2015). Aquaculture, resource use, and the environment. WileyBlackwell, Hoboken, New Jersey, USA.

Boyd, C.E., McNevin, A.A., Racine, P., Quoc Tinh, H., Ngo Minh, H., Viriyatum, R., Paungkaew, D., Engle, C., (2016). Resource Use Assessment of Shrimp, Litopenaeus vannamei and Penaeus monodon, Production in Thailand and Vietnam. Journal of the World Aquaculture Society 48, 201-226.

Boyd, C.E., McNevin, A.A., Davis, R.P., Godumala, R., Mohan, A.B.C., (2018). Production Methods and Resource Use at Litopenaeus vannamei and Penaeus monodon Farms in India Compared with Previous Findings from Thailand and Vietnam. Journal of the World Aquaculture Society 49 (3).

Bottema, M. J., Bush, S. R., \& Oosterveer, P. (2018). Moving beyond the shrimp farm: Spaces of shared environmental risk?. The Geographical Journal.

Bush, S. R., Van Zwieten, P. A., Visser, L., Van Dijk, H., Bosma, R., De Boer, W. F., Verdegem, M. (2010). Scenarios for resilient shrimp aquaculture in tropical coastal areas. Ecology and society $\mathbf{1 5}(2), 15$.

Bush, S. R., Marschke, M. J., (2014). Making social sense of aquaculture transitions. Ecology and Society 19(3), 50.

Bush, S. R., Belton, B., Hall, D., Vandergeest, P., Murray, F. J., Ponte, S., Oosterveer, P., Islam, M. S., Mol, A. P. J., Hatanaka, M., Kruijssen, F., Ha, T. T. T., Little, D. C., Kusumawati, R., (2013). Certify Sustainable Aquaculture? Science 341, 1067-1068.

Bunting, S.W., Kundu, N., Ahmed, N., (2017). Evaluating the contribution of diversified shrimp-rice agroecosystems in Bangladesh and West Bengal, India to social-ecological resilience. Ocean and Coastal Management 148, 63 - 74.

Cardoso-Mohedano, J., Lima-Rego, J., Sánchez-Cabeza, J., Ruiz-Fernández, A., Canales-Delgadillo, J., Sánchez-Flores, E., Paez-Osuna, F., (2018). Sub-tropical coastal lagoon salinization associated to shrimp ponds effluents. Estuarine, Coastal and Shelf Science 203, 72 - 79.

Chitmanat, C., Lebel, P., Whangchai, N., Promya, J., \& Lebel, L. (2016). Tilapia diseases and management in river-based cage aquaculture in northern Thailand. Journal of Applied Aquaculture 28(1), 9-16.

Cock, J., Salazar, M., \& Rye, M. (2015). Strategies for managing diseases in non-native shrimp populations. Reviews in Aquaculture.

Deb, A.K., (1998). Fake blue revolution: environmental and socio-economic impacts of shrimp culture in the coastal areas of Bangladesh. Ocean Coastal Management 41, 63 - 88.

Diana, J., 2009. Aquaculture Production and Biodiversity Conservation. BioScience, 59, 27-38.

Dierberg, F.E., Kiattisimkul, W., (1996). Issues, impacts, and implications of shrimp aquaculture in Thailand. Environmental Management 20, 649 - 666.

Department of Fisheries, (2018). Fisheries statistics of Thailand. http://www.fisheries.go.th/itstat/yearbook/Index.htm

Engle, C. R., McNevin, A., Racine, P., Boyd, C. E., Paungkaew, D., Viriyatum, R., Tinh, H.Q., Minh, H. N., (2017). Economics of sustainable intensification of aquaculture: Evidence from shrimp farms in Vietnam and Thailand. Journal of the World Aquaculture Society 48, 227-239.

FAO (2016a). Sustainable intensification of aquaculture in the Asia-Pacific region. Documentation of successful practices. W. Miao and K. K. Lal, editors. FAO, Bangkok, Thailand.

FAO, (2016b). http://www.fao.org/fishery/countrysector/naso_thailand/en. [Accessed 1 November 2017].

FAO, (2016c). The State of World Fisheries and Aquaculture (2016). Contributing to food security and nutrition for all. Rome. 200 pp.

FAO (2018a). The State of World Fisheries and Aquaculture 2018 - Meeting the sustainable development goals. Rome.

FAO (2018b). http://www.fao.org/fishery/sofia/en [Accessed 1 Dec 2018]. 
Feola, G., Binder, C.R., (2010). Towards an improved understanding of farmers' behaviour: The integrative agent-centred (IAC) framework. Ecological Economics 69(12), 2323-2333.

Feola, G., Binder, C.R. 2010. Identifying and investigating pesticide application types to promote a more sustainable pesticide use. The case of smallholders in Boyacá, Colombia. Crop Protection, 29(6):612-622.

Flaherty, M., Karnjanakesorn, C., (1995). Marine shrimp aquaculture and natural resource degradation in Thailand. Environmental Management 19(1), 27-37.

Flegel, T.W., 2012. Historic emergence, impact and current status of shrimp pathogens in Asia. Journal Invertebrate Pathology 110, 166-173.

Gallino, L. (1993). Dizionario di Sociologia. TEA, Turino.

Godfray, H.C.J., Beddington, J.R., Crute, I.R., Haddad, L., Lawrence, D., Muir, J.F., Pretty, J., Robinson, S., Thomas, S.M., Toulmin, C., (2010). Food Security: The Challenge of Feeding 9 Billion People. Science 327, 812-818.

Goodman, L., (1961). "Snowball Sampling”. Annals of Mathematical Statistics 32, 245-268.

Hamilton, S., 2013. Assessing the Role of Commercial Aquaculture in Displacing Mangrove Forest. Bulletin of Marine Science 89, 585-601.

Ha, T.T.T., Bush, S.R., Mol, A.P.J., Van Dijk, H., (2012a). Organic coasts? Regulatory challenges of certifying integrated shrimp-mangrove production systems in Vietnam. Journal of Rural Studies 28(4), 631 - 639.

Ha, T.T.T., Van Dijk, H., Bush, S.R., (2012b). Mangrove conservation or shrimp farmer's livelihood? The devolution of forest management and benefit sharing in the Mekong Delta, Vietnam. Ocean \& Coastal Management 69, 185 - 193.

Hall, D., (2004). Explaining the diversity of Southeast Asian shrimp aquaculture. Journal of Agrarian Change 4(3), 315-335.

Hall, S.J., Delaporte, A., Phillips, M.J., Beveridge, M., O’Keefe, M., (2011). Blue Frontiers: Managing the Environmental Costs of Aquaculture. The WorldFish Centre, Penang, Malaysia.

Hall, D., (2011). Land Control, Land Grabs, and Southeast Asian Crop Booms. Journal of Peasant Studies 38(4), 837-857.

Hazarika, M. K., Samarakoon, L., Honda, K., Thanwa, J., Pongthanapanich, T., Boonsong, K., \& Luang, K. (2000). Monitoring and impact assessment of shrimp farming in the East Coast of Thailand using remote sensing and GIS. International Archives of Photogrammetry and Remote Sensing 33(B7/2; PART 7), 504-510.

Henriksson, P. J., Rico, A., Zhang, W., Ahmad-Al-Nahid, S., Newton, R., Phan, L. T., ... \& Little, D. C. (2015). Comparison of Asian aquaculture products by use of statistically supported life cycle assessment. Environmental science \& technology 49(24), 14176-14183.

Herbeck, L., Unger, D., Wu, Y., Jennerjahn, T.C., (2013). Effluent, nutrient and organic matter export from shrimp and fish ponds causing eutrophication in coastal and back-reef waters of NE Hainan, tropical China. Continental Shelf Research 57, 92-104.

Hubbard, D., W. (2014), How to Measure Anything: Finding the Value of "Intangibles" in Business, 3rd ed, John Wiley \& Sons, Inc., New Jersey, USA.

Hoque, S. F., Quinn. C.H., Sallu, S., (2018). Differential livelihood adaptation to social-ecological change in coastal Bangladesh. Regional Environmental Change 18, 451-463.

Huitric, M., Folke, C., Kautsky, N., (2002). Development and government policies of the shrimp farming industry in Thailand in relation to mangrove ecosystems. Ecological Economics 40(3), 441-455.

Islam, M.S., Milstein, A., Wahab, M.A., Kamal, A.H.M., Dewan, S., (2005). Production and economic return of shrimp aquaculture in coastal ponds of different sizes and with different management regimes. Aquaculture International 13, 489 - 500.

Janetkitkosol, W., Somchanakij, H., Eiamsa-ard, M., Supongpan, M., (2003). Strategic review of the fishery situation in Thailand. in: Silvestre, G., Garces, L., Stobutzki, I., Ahmed, M., Valmonte-Santos, R.A., Luna, C., Lachica-Aliño, L., Munro, P., Christensen, V., Pauly, D. (Eds.), Assessment, Management and Future Directions for Coastal Fisheries in Asian Countries. WorldFish Centre Conference Proceedings 67, WorldFish Centre, Penang, pp. 915-956. 
Jespersen, K. S., Kelling, I., Ponte, S., \& Kruijssen, F. (2014). What shapes food value chains? Lessons from aquaculture in Asia. Food policy 49, 228-240.

Joffre, O.M., Bosma, R.H., Bregt., A.K., van Zwieten., P.A.M., Bush., S.R., Verreth., J.A.J., (2015). What drives the adoption of integrated shrimp mangrove aquaculture in Vietnam? Ocean \& Coastal Management 114, 53-63.

Joffre, O. M., Bosma, R. H., Ligtenberg, A., Ha, T. T. P., \& Bregt, A. K. (2015b). Combining participatory approaches and an agent-based model for better planning shrimp aquaculture. Agricultural Systems, 141, 149-159.

Joffre, O.M., Bosma, R.H., (2009). Typology of shrimp farming in Bac Lieu Province, Mekong Delta, using multivariate statistics. Agriculture, Ecosystems and Environment 132, 153-159.

Joffre, O. M., Poortvliet, P. M., \& Klerkx, L. (2018). Are shrimp farmers actual gamblers? An analysis of risk perception and risk management behaviours among shrimp farmers in the Mekong Delta. Aquaculture.

Joffre, O.M., Poortvliet, P.M. \& Klerkx, L. (2019). To cluster or not to cluster farmers? Influences on network interactions, risk perceptions, and adoption of aquaculture practices. Agricultural Systems 173, 151-160.

Johnson, K., C. Engle, and B. Wagner.2014. Comparative economics of U.S. catfish production strategies: evidence from a cross-sectional survey. Journal of the World Aquaculture Society 45(3):279-289.

Kongkeo, H., (1997). Comparison of intensive shrimp farming systems in Indonesia, Philippines, Taiwan and Thailand. Aquaculture Research 28, 789-796.

Kumar, G., \& Engle, C. R. (2016). Technological advances that led to growth of shrimp, salmon, and tilapia farming. Reviews in Fisheries Science \& Aquaculture 24(2), 136-152.

Kumar, G. and Engle, C. (2017). Economics of intensively aerated catfish ponds. Journal of the World Aquaculture Society 48(2):320-332.

Kusumawati, R., Bush, S.R., Visser, L.E., (2013). Can patrons Be bypassed? Frictions between local and global regulatory networks over shrimp aquaculture in East Kalimantan. Soc. Natur. Resources. 26 (8), 898 - 911.

Lebel, L., Tri, N. H., Saengnoree, A., Pasong, S., Buatama, U., Thoa, L. K., (2002). Industrial transformation and shrimp aquaculture in Thailand and Vietnam: pathways to ecological, social, and economic sustainability? AMBIO: A Journal of the Human Environment 31(4), 311-323.

Lebel, L., Lebel, P., \& Lebel, B. (2016). Impacts, Perceptions and Management of Climate-Related Risks to Cage Aquaculture in the Reservoirs of Northern Thailand. Environmental management 58(6), 931-945.

Lebel, L., \& Lebel, P. (2018). Emotions, attitudes, and appraisal in the management of climate-related risks by fish farmers in Northern Ireland. Journal of Risk Research 21(8), 933-951.

Le Bihan, V., Pardo, S., \& Guillotreau, P. (2013). Risk perception and risk management strategies of oyster farmers. Marine Resource Economics 28(3), 285-304.

Leaño, E.M., Mohan, C.V., (2012). Early Mortality Syndrome threatens Asia’s shrimp farms. Global Aquaculture Advocate 38-39.

Naylor, R. L., Goldburg, R. J., Mooney, H., Beveridge, M., Clay, J., Folke, C., Kautsky, N., Lubchenco, J., Primavera, J., Williams, M., (1998). Nature's subsidies to shrimp and salmon farming. Science 282(5390), 883-884.

Naylor, R. L., Goldburg, R.J., Primavera, J.H., Kautsky, N., Beveridge, M.C.M., Clay, J., Folke, C., Lubchenco, J., Mooney, H., Troell, M. (2000). Effect of aquaculture on world fish supplies. Nature 405, 1017-1024.

Naylor, R.L., Hardy, R.W., Bureau, D.P., Chiu, A., Elliott, M., Farrell, A.P., Forster, I., Gatlin, D.M., Goldburg, R.J., Hua, K., Nichols, P.D., (2009). Feeding aquaculture in an era of finite resources. PNAS 106 (36), 15103-15110.

Neiland, A.E., Soley, N., Varley, J.B., Whitmarsh, D.J., (2001). Shrimp aquaculture: economic perspectives for policy development. Marine Policy, 25, 265-279.

Nghia, N.H., Jepsen, M.R., (2017). Dependency on aquaculture in northern Vietnam. Aquaculture International 25(2), 881-891. 
Nguyen, P., Rodela, R., Bosma, R., Bregt, A., \& Ligtenberg, A. (2018). An Investigation of the Role of Social Dynamics in Conversion to Sustainable Integrated Mangrove-Shrimp Farming in Ben Tre Province, Vietnam. Singapore Journal of Tropical Geography, 39(3), 421-437.

Niles, M. T., Brown, M., \& Dynes, R. (2016). Farmer's intended and actual adoption of climate change mitigation and adaptation strategies. Climatic Change 135(2), 277-295.

Pauly, D., Zeller, D., (2016). Catch reconstructions reveal that global marine fisheries catches are higher than reported and declining. Nature Communications 7, 10244.

Paul, B.G., Vogl, C.R., (2011). Impacts of shrimp farming in Bangladesh: Challenges and alternatives. Ocean \& Coastal Management 54, 201-211.

Polidoro, B.A., Carpenter, K.E., Collins, L., Duke, N.C., Ellison, A.M., Ellison, J.C., Farnsworth, E.J., Fernando, E.S., Kathiresan, K., Koedam, N.E., Livingstone, S.R., Miyagi, T., Moore, G.E., Nam, V.N., Ong, J.E., Primavera, J.H., Salmo, S.G., III, Sanciangco, J.C., Sukardjo, S., Wang, Y., Yong, J.W.H., (2010). The Loss of Species: Mangrove Extinction Risk and Geographic Areas of Global Concern. PLOS ONE 5(4), 10095.

Primavera, J.H., (1993). A critical review of shrimp pond culture in the Philippines. Reviews in Fisheries Science 1, 151 - 201.

Primavera, J. H., (1997). Socio-economic impacts of shrimp culture. Aquaculture research 28(10), 815-827.

Primavera, J.H., (1998). Tropical shrimp farming and its sustainability. In: De Silva, S. (Ed.), Tropical Mariculture. Academic Press, London, pp. 257 - 289.

Primavera, J.H., (2006). Overcoming the impacts of aquaculture on the coastal zone. Ocean \& Coastal Management 49, 531-545.

Piamsomboon, P., Inchaisri, C., and Wongtavatchai, J., (2015). White spot disease risk factors associated with shrimp farming practices and geographical location in Chanthaburi province, Thailand. Diseases of aquatic organisms 117(2), 145-153.

Putth, S., Polchana, J., (2016). Current status and impact of early mortality syndrome (EMS)/acute hepatopancreatic necrosis disease (AHPND) and hepatopancreatic microsporidiosis (HPM) outbreaks on Thailand s shrimp farming. In R. V. Pakingking Jr., E. G. T. de Jesus-Ayson, \& B. O. Acosta (Eds.), Addressing Acute Hepatopancreatic Necrosis Disease (AHPND) and Other Transboundary Diseases for Improved Aquatic Animal Health in Southeast Asia: Proceedings of the ASEAN Regional Technical Consultation on EMS/AHPND and Other Transboundary Diseases for Improved Aquatic Animal Health in Southeast Asia, 22-24 February 2016, Makati City, Philippines (pp. 79-87). Tigbauan, Iloilo, Philippines: Aquaculture Department, Southeast Asian Fisheries Development Centre.

Richards, D. R., Friess, D. A., (2016). Rates and drivers of mangrove deforestation in Southeast Asia, 2000-2012. Proceedings of the National Academy of Sciences 113(2), 344-349.

Samerwong, P., Bush, S.R., Oosterveer, P., (2018). Implications of multiple national certification standards for Thai shrimp aquaculture. Aquaculture 493, 319-327.

Shang, Y.C., (1981). Aquaculture economics: basic concepts and methods of analysis. Westview Press, Boulder, CO, p. 153.

Smith, M. D., Roheim, C.A., Crowder, L.B., Halpern, B.S., Turnipseed, M., Anderson, J., Asche, F., Bourillon, L., Guttormsen, A.G., Khan, A., Liguori, L.A., McNevin, A., O’Connor, M.I., Squires, D., Tyedmers, P., Brownstein, C., Carden, K., Klinger, D.H., Sagarin, R., Selkoe, K.A. (2010). Sustainability and global seafood. Science 327, 784.

Stevenson, J.R., Irz, X.T., Alcalde, R-G., Morrisens, P., Petit, J., (2007). An empirical typology of brackish-water pond aquaculture systems in the Philippines: a tool to aid comparative study in the sector. Aquaculture Economic Management 11(2), 171-193.

Tacon, A.G.J., Metian, M., (2008). global overview on the use of fish meal and fish oil in industrially compounded aquafeeds: trends and future prospects. Aquaculture 285, 146-158.

Tendencia, E.A., Bosma, R.H., Verdegem, M.C.J., Verreth, J.A.J., (2013). The potential effect of greenwater technology on water quality in the pond culture of Penaeus monodon Fabricius. Aquaculture Research 46(1), 1 - 13.

Thakur, K., Patanasatienkul, T., Laurin, E., Vanderstichel, R., Corsin, F., Hammell, L., (2018). Production characteristics of intensive whiteleg shrimp (Litopenaeus vannamei) farming in four Vietnam Provinces. Aquaculture Research. 49(8), 2625-2632. 
1060 Tidwell, J.H., 2012. Aquaculture Production Systems. Blackwell Publishing, Oxford.

1061 Valiela, I., Bowen, J. L., and York, J. K., (2001). Mangrove Forests: One of the World's Threatened Major Tropical Environments: At least 35\% of the area of mangrove forests has been lost in the past two decades, losses that exceed those for tropical rain forests and coral reefs, two other well-known threatened environments. Bioscience 51(10), 807-815.

Vandergeest, P., Flaherty, M., Miller, P., (1999). A political ecology of shrimp aquaculture in Thailand. Rural Sociology 64(4), 573-596.

Vandergeest, P., (2007). Certification and Communities: Alternatives for Regulating the Environmental and Social Impacts of Shrimp Farming. World Development 35(7), 1152-1171.

Vandergeest, P., Ponte, S., \& Bush, S. (2015). Assembling sustainable territories: space, subjects, objects, and expertise in seafood certification. Environment and Planning a, 47(9), 19071925.

Wanasuk, K., Siriburananoon, S., (2017). Thai Shrimp Industry Outlook. Bank of Thailand.

\section{Supplementary Material}

Table 1. List of the questions used in the survey conducted with shrimp farmers in Chanthaburi

\section{Province, and how the questions relate to specific components of the IAC Framework.}

\begin{tabular}{|c|c|c|}
\hline $\begin{array}{l}\text { Component of IAC } \\
\text { Framework }\end{array}$ & Factor to measure & Survey question \\
\hline $\begin{array}{l}\text { Contextual factors } \\
\text { (socio-economic) }\end{array}$ & Age & \\
\hline $\begin{array}{l}\text { Contextual factors } \\
\text { (socio-economic) }\end{array}$ & Level of education & What is your highest educational level reached? \\
\hline $\begin{array}{l}\text { Contextual factors } \\
\text { (socio-economic) }\end{array}$ & $\begin{array}{l}\text { Member of a shrimp farmer } \\
\text { group (frequency of attendance } \\
\text { to meetings) }\end{array}$ & Are you a member of a Shrimp Farmers' Group? \\
\hline $\begin{array}{l}\text { Contextual factors } \\
\text { (socio-economic) }\end{array}$ & $\begin{array}{l}\text { Received training on farming } \\
\text { practices from research group } \\
\text { or shrimp farmer group }\end{array}$ & $\begin{array}{l}\text { Have you received formal training and/or technical assistance in shrimp } \\
\text { farming? }\end{array}$ \\
\hline $\begin{array}{l}\text { Contextual factors } \\
\text { (socio-economic) }\end{array}$ & & $\begin{array}{l}\text { Do you have access to the technical equipment needed to farm shrimp } \\
\text { intensively? }\end{array}$ \\
\hline $\begin{array}{l}\text { Contextual factors } \\
\text { (socio-economic) }\end{array}$ & Size of shrimp farm (area) & $\begin{array}{l}\text { What is the size of your farm (rai)? } \\
\text { What was the land used for before the shrimp ponds were built? }\end{array}$ \\
\hline $\begin{array}{l}\text { Contextual factors } \\
\text { (socio-economic) }\end{array}$ & Number of shrimp ponds & $\begin{array}{l}\text { How many ponds are on the farm? } \\
\text { How many of these ponds did you use in the last harvest? } \\
\text { For how many years have the ponds been in use? } \\
\text { Of the ponds used in the last harvest, please indicate for each pond: } \\
\text { Area of pond (rai) } \\
\text { What products were produced (e.g. shrimp, fish.) } \\
\text { Pond stocking density (no. per pond) }\end{array}$ \\
\hline
\end{tabular}




\begin{tabular}{|c|c|c|}
\hline $\begin{array}{l}\text { Contextual factors } \\
\text { (socio-economic) }\end{array}$ & $\begin{array}{l}\text { Total annual production of } \\
\text { shrimp }\end{array}$ & $\begin{array}{l}\text { How many crops of shrimp did you produce in the past } 12 \text { months? } \\
\text { The last time you harvested your ponds, what was the total weight of your } \\
\text { harvest }(\mathrm{kg}) ?\end{array}$ \\
\hline $\begin{array}{l}\text { Contextual factors } \\
\text { (socio-economic) }\end{array}$ & $\begin{array}{l}\text { Average farm labour units } \\
\text { (people/year) }\end{array}$ & In the past 12 months, did anyone help you with the running of the farm? \\
\hline $\begin{array}{l}\text { Contextual factors } \\
\text { (socio-economic) }\end{array}$ & Land ownership status & Are you the owner of the shrimp ponds or are they leased? \\
\hline $\begin{array}{l}\text { Contextual factors } \\
\text { (socio-economic) }\end{array}$ & Annual operating costs: & $\begin{array}{l}\text { The last time you harvested your ponds, what was the cost of producing the } \\
\text { harvest (baht)? }\end{array}$ \\
\hline $\begin{array}{l}\text { Contextual factors } \\
\text { (socio-economic) }\end{array}$ & $\begin{array}{l}\text { Access to credit/investment } \\
\text { capital }\end{array}$ & Do you have access to credit to assist you with running the farm? \\
\hline $\begin{array}{l}\text { Contextual factors } \\
\text { (socio-economic) }\end{array}$ & Level of outstanding debt & Do you currently have any debt from shrimp farming? \\
\hline $\begin{array}{l}\text { Contextual factors } \\
\text { (socio-economic) }\end{array}$ & Annual income & What proportion of your total income normally comes from shrimp farming? \\
\hline $\begin{array}{l}\text { Contextual factors } \\
\text { (production) }\end{array}$ & Location of shrimp farm & What is the location of your shrimp farm? (indicate on map) \\
\hline $\begin{array}{l}\text { Contextual factors } \\
\text { (production) }\end{array}$ & Seasonal weather conditions & $\begin{array}{l}\text { During the rainy season, do you change the amount of shrimp you stock in your } \\
\text { ponds? }\end{array}$ \\
\hline $\begin{array}{l}\text { Contextual factors } \\
\text { (production) }\end{array}$ & $\begin{array}{l}\text { Disease frequency on shrimp } \\
\text { farm }\end{array}$ & $\begin{array}{l}\text { How many times did your shrimp farm experience disease outbreaks in the last } \\
2 \text { years? }\end{array}$ \\
\hline $\begin{array}{l}\text { Contextual factors } \\
\text { (production) }\end{array}$ & $\begin{array}{l}\text { Shrimp mortality due to disease } \\
\text { outbreak }\end{array}$ & $\begin{array}{l}\text { The last time you harvested your ponds, approximately what proportion of } \\
\text { your shrimp survived? }\end{array}$ \\
\hline $\begin{array}{l}\text { Contextual factors } \\
\text { (production) }\end{array}$ & $\begin{array}{l}\text { Frequency of erosion of pond } \\
\text { dykes }\end{array}$ & Have you observed erosion of the pond dykes on your farm? \\
\hline Habit & $\begin{array}{l}\text { Number of years as } \\
\text { intensive/extensive shrimp } \\
\text { farmer }\end{array}$ & $\begin{array}{l}\text { How long have you been farming shrimp? } \\
\text { Has the amount of shrimp that you produce changed over the past } 2 \text { years? } \\
\text { Has the number of different products that you produce (e.g. shrimp, fish) } \\
\text { changed over the past } 2 \text { years? }\end{array}$ \\
\hline Expectations & Perceived risks & Are there any risks associated with intensive shrimp farming? \\
\hline Expectations & Expected market demand & $\begin{array}{l}\text { At the start of the last production cycle, did you expect the market demand } \\
\text { for shrimp to: }\end{array}$ \\
\hline Expectations & Perception of shrimp prices & $\begin{array}{l}\text { At the start of the last production cycle, what price did you expect to sell } \\
\text { your harvest for? (baht } / \mathrm{kg} \text { ) }\end{array}$ \\
\hline Expectations & Perception of price of shrimp & $\begin{array}{l}\text { At the start of the last production cycle, did you expect the market price for } \\
\text { shrimp to: }\end{array}$ \\
\hline Expectations & $\begin{array}{l}\text { Perceived impact of shrimp } \\
\text { farming on water quality }\end{array}$ & $\begin{array}{l}\text { If you increased the amount of shrimp you produce in your ponds, how do you } \\
\text { think this would impact on the water quality in the ponds? }\end{array}$ \\
\hline Expectations & $\begin{array}{l}\text { Perceived impact of shrimp } \\
\text { farming on soil quality }\end{array}$ & $\begin{array}{l}\text { If you increased the amount of shrimp you produce in your ponds, how do you } \\
\text { think this would impact the soil quality in the ponds? }\end{array}$ \\
\hline Expectations & $\begin{array}{l}\text { Whether shrimp farmer expects } \\
\text { a reduction in shrimp disease if }\end{array}$ & $\begin{array}{l}\text { If you increased the amount of shrimp you produce in your ponds, how do you } \\
\text { think this would affect the survival rate of shrimp? }\end{array}$ \\
\hline
\end{tabular}




\begin{tabular}{|c|c|c|}
\hline & $\begin{array}{l}\text { shrimp farm intensity is } \\
\text { reduced/increased }\end{array}$ & \\
\hline $\begin{array}{l}\text { Subjective culture - } \\
\text { social norms }\end{array}$ & $\begin{array}{l}\text { How shrimp farmer is perceived } \\
\text { by others }\end{array}$ & $\begin{array}{l}\text { Is the opinion of __about the amount of shrimp you produce per pond } \\
\text { important to you? } \\
\text { Your spouse/family } \\
\text { Other shrimp farmers } \\
\text { Your local Shrimp Farmer group } \\
\text { Research groups/aquaculture experts } \\
\text { The government } \\
\text { Environmentalist groups } \\
\text { What do you think_ thinks about the amount of shrimp you produce per } \\
\text { pond? }\end{array}$ \\
\hline $\begin{array}{l}\text { Subjective culture - } \\
\text { social norms }\end{array}$ & Social conflict & $\begin{array}{l}\text { What do you think__ would think if you increased the amount of shrimp } \\
\text { you produce per pond? }\end{array}$ \\
\hline $\begin{array}{l}\text { Subjective culture - } \\
\text { social norms }\end{array}$ & $\begin{array}{l}\text { How often shrimp farmer follows } \\
\text { advice from others }\end{array}$ & $\begin{array}{l}\text { How often do you follow advice from___ regarding the amount of shrimp } \\
\text { you stock in your ponds? }\end{array}$ \\
\hline $\begin{array}{l}\text { Subjective culture - } \\
\text { social norms }\end{array}$ & $\begin{array}{l}\text { Perception about production } \\
\text { intensity of other shrimp farmers }\end{array}$ & $\begin{array}{l}\text { At the start of a production cycle, what are the three most important things that } \\
\text { you consider when deciding on how many shrimps to stock in your ponds? }\end{array}$ \\
\hline $\begin{array}{l}\text { Subjective culture - } \\
\text { social norms }\end{array}$ & $\begin{array}{l}\text { Perception about the intensity of } \\
\text { other shrimp farms }\end{array}$ & $\begin{array}{l}\text { Do most shrimp farmers in this area stock shrimp in their ponds at the same } \\
\text { density as you? } \\
\text { Do most shrimp farmers in this area produce the same number of crops per } \\
\text { year as you? }\end{array}$ \\
\hline $\begin{array}{l}\text { Subjective culture - } \\
\text { roles }\end{array}$ & Status of shrimp farmer & What are the 3 most important aspects to being a good shrimp farmer? \\
\hline $\begin{array}{l}\text { Subjective culture - } \\
\text { roles }\end{array}$ & Care for the environment & $\begin{array}{l}\text { "The health of the coastal environment is important to me". } \\
\text { How much do you agree with this statement? }\end{array}$ \\
\hline $\begin{array}{l}\text { Subjective culture - } \\
\text { values }\end{array}$ & Religion & What is your religion? \\
\hline $\begin{array}{l}\text { Physiological } \\
\text { arousal }\end{array}$ & $\begin{array}{l}\text { Feelings associated with shrimp } \\
\text { farming }\end{array}$ & Do you enjoy farming shrimp at this level of intensity? \\
\hline
\end{tabular}

1081

1082

1083

1084 